\title{
Evaluation of Immune Boosting Properties and Combating of Multiple Respiratory Viral Infections by fifteen Euphorbiaceae Plant Extracts
}

\author{
Howaida I. Abd-Alla ${ }^{1, *}$, Heba-tollah M. Sweelam ${ }^{1}$, Walaa A. El-Kashak ${ }^{1}$, Mounir M. El-Safty ${ }^{2}$
}

Howaida I. Abd-Alla ${ }^{1, *}$, Hebatollah M. Sweelam ${ }^{1}$, Walaa A. El-Kashak', Mounir M. El-Safty ${ }^{2}$

${ }^{1}$ Chemistry of Natural Compounds Department, National Research Centre, ElTahrir Street, Dokki, Giza 12622, EGYPT. ${ }^{2}$ Quality Control of SPF Eggs Department, Central Laboratory for Evaluation of Veterinary Biologics, Abbassia 13181, Cairo, EGYPT.

\section{Correspondence}

\section{Howaida I. Abd-Alla}

Chemistry of Natural Compounds Department, National Research Centre, ElTahrir Street, Dokki, Giza 12622, EGYPT.

E-mail: howaida_nrc@yahoo.com

History

- Submission Date: 23-09-2019;

- Review completed: 03-10-2019;

- Accepted Date: 21-10-2019.

DOI : 10.5530/pj.2019.11.230

Article Available online http://www.phcogj.com/v11/i6s

\section{Copyright}

(C) 2019 Phcogi.Com. This is an openaccess article distributed under the terms of the Creative Commons Attribution 4.0 International license.

\begin{abstract}
Objective: Fifteen Euphorbiaceae plant extracts were evaluated for their antiviral and immune boosting properties. Methods: The maximum non-toxic concentration of each extract in specific pathogen-free embryonated chicken eggs was estimated and their antiviral efficacy was determined in terms of reduction in viral titers, measured by the hemagglutination inhibition (HI) assay. The antiviral efficacy was compared with ribavirin. The active extract was further subjected to estimation of total polyphenolic and flavonoid contents. Also, GC/ MS analysis was used to analyze its unsaponifiable and saponifiable matters. Results: The cytotoxic concentration fifty $\left(\mathrm{CC}_{50}\right.$ ) of Breynia distacha recorded the value of $>200$ and $>300$ for Newcastle disease virus (NDV) and avian influenza virus (AIV) H5N1, respectively. This extract showed antiviral inhibition concentration $\left(\mathrm{IC}_{50}\right)$ values of $\leq 2$ and $\leq 3$, respectively and antiviral therapeutic index of $100 \%$ compared with ribavirin as standard. The serum of the vaccinated chicks treated with $B$. distacha has recorded the highest $\mathrm{HI}$ titers (7.1 and $8.3 \log 2$ ) at the day of 28 post vaccination with high protection percentage (100 and $90 \%$ ) post NDV and AIV H5N1 challenge, respectively. Also, a high HI titer (6.9 log2) was recorded in serum of the vaccinated chicks treated with Aleurites moluccana, Jatropha curcas, Ricinus communis, Putranjiva roxburghii with protection percentage of $95-100 \%$ post-NDV challenge. GC/MS analysis allowed identification of $91.10 \%$ of the total unsaponifiable matter, (1-heptatriacotanol represented the major component, $24.61 \%$ ) and $82.51 \%$ of the fatty acid methyl esters content (methyl palmitate represented the major component, $26.13 \%$ ). Conclusion: This study highlighted the potential of many Euphorbiaceae plants especially $B$. distacha, to be new candidate of plant-based prototypes that carry antiviral and immunogenic features against respiratory viral infections.
\end{abstract}

Key words: Euphorbiaceae, Respiratory viral infections, SPF-ECEs, Immune, Hemagglutination, GC/MS.

\section{INTRODUCTION}

Interest in a large number of traditional natural products has increased. ${ }^{1,2}$ Natural products, such as hydroalcoholic and aqueous extracts, use in allopathic medicine, continue to provide bioactive agents because of the unmatched availability of chemical diversity. ${ }^{2}$ They were explored as sources of potential drug candidates for the treatment of infectious diseases of human and animals. The major threat for sustainable growth of poultry production comes from a plethora of viral pathogens. ${ }^{3}$ Newcastle disease (ND) and avian influenza (AI) of the $\mathrm{H} 5 \mathrm{~N} 1$ subtype have been recognized as the most important respiratory tract infection pathogens that have significantly threatened the poultry sector in Egypt. ${ }^{4,5}$ In recent years, poultry industry faced severe outbreaks due to mixed infections of these two viruses which were causing high mortality and great economic losses. ${ }^{4,5}$ Both viruses are contagious and widespread avian disease affecting most species of birds. The ND affected birds exhibit the symptoms of irregularities of respiratory, nervous and digestive system. ${ }^{6} \mathrm{NDV}$ has public health importance that it can produce a transitory conjunctivitis in humans. ${ }^{6}$ The avian influenza type-A virus (H5N1) is the most devastating and has caused unprecedented losses to poultry industry and poses a threat to human. Outbreaks of influenza virus infections in commercial poultry flocks appeared to be associated with severe clinical signs, variable high mortality (20\%-65\%) and high reduction in egg production (up to $75 \%$ ) as reported by Suarez (2008). ${ }^{7}$ Although vaccines have long been available and administered to control these respiratory viral pathogens, they remain an ongoing threat to commercial flocks. Unfortunately, vaccines against both viruses do not provide sterile immunity, and in many areas of the world vaccines are used to prevent losses from sickness and death. ${ }^{6}$ Endemicity of NDV and AI circulation in poultry especially in Egypt could further aggravate the current situation. Antiviral drugs cause more risk than benefit due to their low efficiency and viral resistance. This led to a continuous search for new agents offering both selectivity towards antiviral and immunostimulant activities. The plant may have a possible indirect activity in vivo, such as stimulation of certain host defenses, including the immune system. The selection of crude plant extracts for screening programs

Cite this article: Abd-Alla HI, Sweelam HM, El-Kashak WA, El-Safty MM. Evaluation of Immune Boosting Properties and Combating of Multiple Respiratory Viral Infections by fifteen Euphorbiaceae Plant Extracts. Pharmacog J. 2019;11(6)Suppl:1490-1503. 
has the potential of being more successful in its steps than screening of pure compounds isolated from the products. ${ }^{8}$ The spurge family, Euphorbiaceae occupied a special place in the realm of plant families and is scientifically reported for its antiviral, antimicrobial, anticancer, cytotoxic, and antitumor activities. ${ }^{9}$ In this respect, the present work aims to search for the use of plants of the Euphorbiaceae family to combat emerging infectious poultry diseases. Fifteen species belong to this family, are widely distributed and easily available throughout various geographical locations in Egypt, ${ }^{10}$ were selected and subjected to evaluate their potential anti-viral activities against respiratory tract infection pathogens in specific pathogen-free (SPF) chicken embryos and evaluation of immune boosting properties of these substances in SPF chicks. These plant species are well known to have their traditional claims for cure and/or reduce symptoms of various disorders including infectious diseases of animal and human among folk cultures.

\section{MATERIALS AND METHODS}

\section{Plant material}

Different plants with their different parts were collected from various geographical locations in Egypt (Table 1). The identification of plant was performed by Treas Labib, Herbarium Section, El-Orman Botanical Garden, Giza, Egypt and by Dr. S.S. El-Khanagry, Department of Flora and Phyto-taxonomy Research, Horticultural Research Institute, Egypt. Voucher specimens were deposited in the herbarium of the National Research Centre (CAIRC), Giza, Egypt.

\section{Preparation of hydroalcoholic extracts}

The plant materials were air dried and crushed into powder. Each powder was, separately, sealed in black plastic bags at room temperature $\left(25 \pm 2{ }^{\circ} \mathrm{C}\right.$ and $70 \pm 5 \%$ relative humidity) for later study. The dried materials ( $200 \mathrm{~g})$ were separately subjected to continuous extraction apparatus (Soxhlet) exhaustively using solvents $70 \%$ aqueous methanol. The extraction was continued till exhaustion. The solvent was stripped off by distillation under reduced pressure at a temperature not exceeding $40^{\circ} \mathrm{C}$ using rotatory evaporator and stored at $4^{\circ} \mathrm{C}$.

\section{Specific pathogen-free HA test before use}

One-day-old fertile specific pathogen-free (SPF) eggs were taken from the National Project Nile SPF eggs, Koom Oshiem, Fayoum, Egypt. The eggs were used for propagation and titration of virus. They were kept in the egg incubator at $37^{\circ} \mathrm{C}$ with humidity $60-80 \%$ till the age of 9-11 day old. All eggs and birds were kept in biosafety isolators.

\section{Chicken erythrocytes}

Freshly collected chick erythrocytes (1\% and $10 \%)$ prepared in saline solution after several washes were used in hemagglutination assay (HA).

Newcastle disease virus and highly pathogenic avian influenza virus $\mathrm{H} 5 \mathrm{~N} 1$

\section{Viruses}

The viruses of Newcastle disease virus (NDV) and avian influenza virus AIV H5N1 were obtained from the bank of strains of our Central Laboratory for Evaluation of Veterinary Biologics (CLEVB), Abbasia, Egypt. Avian influenza AI of Accession No. AFI44355 and ND of accession no. Genotype7: KM288609 were used.

\section{Vaccines}

The vaccines with titer of $10^{8.2}$ and $10^{8}$ EID $50 / \mathrm{mL}$ (embryo infective dose) were used for vaccination of the experimental birds for avian influenza $\mathrm{AI}$ and $\mathrm{ND}$, respectively.

\section{Hemagglutination test (HA)}

It was applied for calculating the titer of virus in the collected allantoic fluid of all inoculated groups of SPF-embryonated chicken eggs (SPFECEs) according to Office International Des Epizooties OIE (2002). ${ }^{25}$ Hemagglutination inhibition (HI) test all serum samples from the groups were collected for estimation of antibody titers against the investigated virus using hemagglutination inhibition (HI) assay. ${ }^{26}$ In brief, two-fold serial dilution of $25 \mu \mathrm{L}$ serum was made with phosphatebuffered saline (PBS) in V-bottomed microtiter plates (Nunc) up to 10th well. $25 \mu \mathrm{L}$ of 4 hemagglutinating units of virus or antigen was added up to 11th well. The plates were kept at room temperature for more than 30 minutes to facilitate antigen-antibody reaction. Then, $50 \mu \mathrm{L}$ of $1 \%(\mathrm{v} / \mathrm{v})$ chicken red blood cells (RBCs) suspension was added to each well. The 11th well contains antigen and RBCs as the positive control, and the 12th well contains only RBCs as the negative control. After gentle mixing, the RBCs were allowed to settle at room temperature for 40 minutes, and agglutination was assessed by tilting the plates. The samples showing peculiar central button shaped settling of RBCs were recorded as positive and maximum dilution of each sample causing HI was considered the end point, which was used to estimate the HI titer. The HI titer of each serum sample was expressed as reciprocal of the serum dilution (OIE 2002). ${ }^{25}$

\section{Vaccination of birds}

The experimental birds were vaccinated via drinking water for NDV and subcutaneous injection (S/C) for AIV. The commonly used serological test, HI assay, performed on vaccinated chicks' sera was used for potency testing of vaccines after the day of 28 post vaccination. ${ }^{26}$ The assay was used to estimate antibody titers. The vaccine was tittered by measuring the hemagglutinating activity using a microplate HA test.

\section{Cytotoxicity concentration fifty $\left(\mathrm{CC}_{50}\right)$}

Each plant extract was diluted 1: 50 in Modified Eagle Medium MEM. ${ }^{26}$ It was then filtered through a sterile syringe filter $0.2 \mathrm{~mm}$ pore diameter. The filtrate equivalent to $200 \mathrm{mg}$ dried plant material and $1 \%$ ethanol, was the starting material. Serial dilutions of each extract were made (in duplicate), in MEM $+0.1 \%$ serum, across a row of wells in an empty 96 well microtest tray. Groups of SPF-ECE ${ }_{S}$ were inoculated with different concentration of each tested sample separately for calculation of $\mathrm{CC}_{50}$. Un-inoculated SPF eggs were always included as control of embryo. The eggs inoculated via allantoic cavity and were incubated for 6 days post-inoculation (PI) at $37^{\circ} \mathrm{C}$ with humidity $60-80 \% . \mathrm{CC}_{50}$ of each test sample was determined as the minimal concentration of sample that induced any embryos mortalities or any deviation than normal control embryos in $50 \%$ of embryonated chicken eggs.

\section{Inhibition concentration and therapeutic index}

Other group of SPF-ECE $\mathrm{S}_{\mathrm{S}}$ were inoculated with mixture of minimal cytotoxic concentration of different tested extract separately with each virus separately $(0.2 \mathrm{~mL}$ per egg) for calculation of the antiviral inhibitory concentration fifty $\left(\mathrm{IC}_{50}\right){ }^{27,28}$ Un-inoculated SPF eggs were always included as control of embryo. The eggs inoculated via allantoic cavity and were incubated for 6 days PI at $37^{\circ} \mathrm{C}$ with humidity 60 $80 \%$. The $\mathrm{IC}_{50}$ of tested samples was assayed as the concentration the compound that fully inhibited virus effect in $50 \%$ of embryonated chicken eggs. The therapeutic index (TI) for each sample was also determined ffrom $\mathrm{CC}_{50} / \mathrm{IC}_{50}$. The antiviral efficacy was compared with ribavirin, a broad spectrum antiviral drug.

\section{In vitro antiviral assay}

The antiviral properties of the hydroalcoholic extract of plants against virus replication in SPF chicken embryos were investigated using 
Table 1: The selected hydro-alcoholic plant extracts collected from Euphorbiaceae and their traditional uses, region of collection and vernacular name.

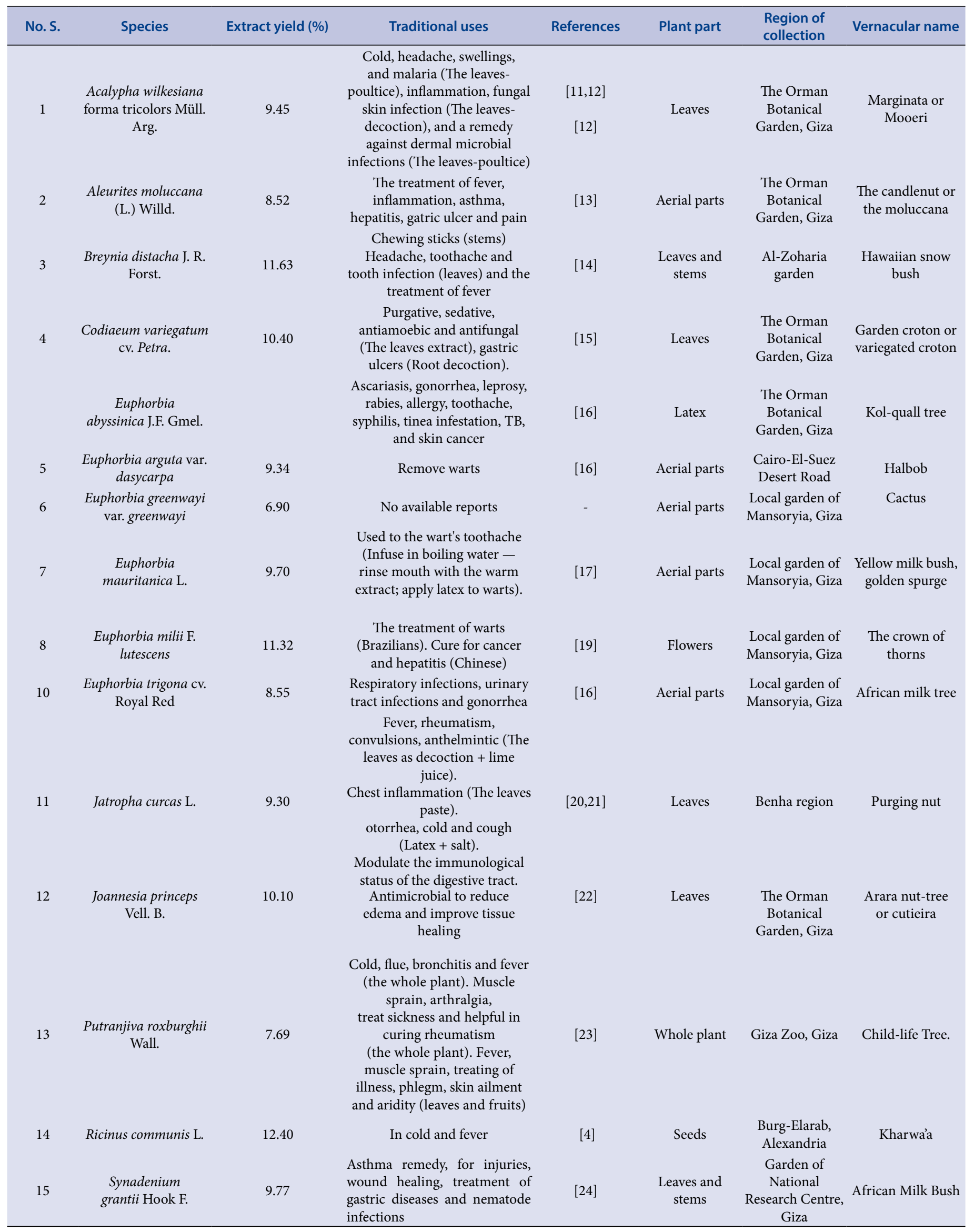


the non-toxic concentration each sample (lower than $\left.\mathrm{CC}_{50}\right){ }^{27}$ The assay was carried out as the following the virus $(0.2 \mathrm{~mL})$ was mixed and each sample $(0.2 \mathrm{~mL})$, separately, and incubation for one hour in room temperature. Twelve -fold serial dilutions of the mixtures were performed. For each virus; groups (365 eggs) of 9-11-days-old SPF were inoculated by varying serial dilutions (from $1^{\text {st }}$ dilution to $12^{\text {th }}$ dilution each dilution in five eggs) of each mixture $(0.2 \mathrm{~mL}$ per egg) were inoculated via allantoic route. Daily examination of the inoculated eggs, deaths within 24 hours post -inoculation (PI) were discarded. The mortality between the $2^{\text {nd }}$ to $6^{\text {th }}$ day of life PI considered being specific. Virus infectivity control and the tested samples toxicity controls will be inoculated via the chorioallantoic cavity. Test eggs will be incubated for $3-4$ days at $37^{\circ} \mathrm{C}$ and $80 \%$ humidity.

\section{Determination of viral titer}

The viral titer was calculated by measuring $50 \%$ embryo infectious dose $\left(E_{50}\right) .{ }^{29}$ One hundred micrograms of dried virus of NDV or AIV were added into $10 \mathrm{~mL}$ of the PBS buffer ( $\mathrm{pH}$ 7.2). The obtained supernatant was diluted by a serial of 10 -fold dilution, and $10^{-6}, 10^{-7}$ and $10^{-8}$ were inoculated into the allantoic cavity of five 10-day-old SPF-ECEs respectively and incubated at $37^{\circ} \mathrm{C}$ for $120 \mathrm{~h}$. Dead embryos were discarded at $24 \mathrm{~h}$ post inoculation. Eggs were chilled at $4^{\circ} \mathrm{C}$ and the allantoic fluid was harvested and measured by micro technique of the hemagglutination (HA) test.26,30 The EID50 was calculated according to the Reed-Muench method.

\section{Evaluation of immune boosting properties in SPF chicks and challenge study}

\section{Chicks and virus antibodies}

Evaluation of immune boosting properties of different extracts was examined in SPF chicks. For each virus, three hundred and forty SPF chicks were divided into seventeen groups (20 chicks/group, separated in biosafety isolator). At 7 days old, random birds from each group were examined for virus antibodies by HI test to check maternal antibodies. All chicks were proved to be free from virus antibodies by $\mathrm{HI}$ test.

\section{$H$ lantibodies in serum}

Half a milliliter of blood samples was centrifuged at 2,200 g/min for $10 \mathrm{~min}$ at $4^{\circ} \mathrm{C}$ to collect serum. Each serum sample was transferred to $1.5 \mathrm{~mL}$ of pre-labeled Eppendorf tube and preserved at $4^{\circ} \mathrm{C}$ until tested individually by hemagglutination inhibition test. ${ }^{26,30}$

\section{Experimental design}

For each virus; group 1 served as the control vaccinated-nontreated group where the experimental chicks ( 20 chicks) were vaccinated with inactivated virus vaccine. The experimental birds were vaccinated via drinking water for NDV and S/C for AIV. The groups 2-15 served as the vaccinated-treated groups. The groups $2-16$, separately, vaccinated with the virus vaccine and received $6 \mathrm{~mL}$ of the diluted nontoxic concentration of each tested samples. The sample was added to the drinking water every day for 28 days post vaccination. Each group was separated in biosafety isolator. The group 17 (20 chicks) was kept in a separate isolator and served as non-vaccinated no-treated negative control. The control non-vaccinated and the control vaccinated groups were not given any supplements except water and feed during the experiment. Blood samples were collected individually from groups from jugular vein for estimation of the $\mathrm{HI}$ antibody titer in serum of vaccinated chicks at day 28 post vaccination by $\mathrm{HI}$ technique using standard virus antigen (4HA units)..$^{26,30}$ Comparison between humoral response of the vaccinated group and other vaccinated groups received each extract separately as immunostimulant was carried out. After collection of blood samples, the vaccinated groups and control group were challenged with a local isolated strain of NDV and AIV. ${ }^{31}$

\section{Evaluation of immune boosting properties of different samples in SPF chicks}

Blood samples were collected individually from jugular vein at the day 28 post-vaccination ( $\mathrm{dpv}$ ) for potency test by calculation of the $\mathrm{HI}$ antibody titer in serum of vaccinated chicks. Comparing humoral response of the vaccinated group. HI antibody was recorded in the control vaccinated group received the vaccine without receiving plant extract and other vaccinated treated groups which received the tested extracts separately. ${ }^{27,28}$

\section{Compliance with ethics requirements}

The chicks' care and experimental protocols were in compliance with guidelines of ethical standards released by CLEVB on animal care and use. All efforts were made to ensure ethical and human treatment of the chicks. To conduct study using standard $\mathrm{HI}$ assay demands an immense supply of virus, which in turn requires the implementation of virus propagation protocols and involvement of specially trained personnel. In addition, particularly in the case of highly infective influenza strain, level II or III bio-safety laboratory spaces and protocols would also be mandatory for safe implementation of virus culture. In our laboratory (CLEVB), the facility and laboratory equipment are monitored and maintained by an on-site Facilities Engineering Unit and by a Calibration Laboratory accredited to the ISO 17025 Standard. All environmental and biocontainment specifications are consistent with current government requirements.

\section{Chemical composition}

\section{Determination of total phenolics and flavonoids content}

The total phenolics content of individual plant extract was estimated using the Folin-Ciocalteu reagent. ${ }^{32}$ Briefly, an aliquot $(4 \mu \mathrm{L})$ of $B$. distacha J. R. Forst extract was mixed with $1.0 \mathrm{~mL}$ of Folin-Ciocalteu reagent (diluted 10 -fold with distilled water) and $0.8 \mathrm{~mL}$ of $7.5 \%$ sodium carbonate were added to neutralize the reaction. The tube was mixed and allowed to stand for $30 \mathrm{~min}$ and the absorption at $760 \mathrm{~nm}$ was measured against a blank, which contained $400 \mu \mathrm{L}$ of ethanol in place of sample. The amount of total phenolic content was calculated using regression equation of gallic acid, used as standard positive control given by $\mathrm{y}=0.00181 \mathrm{x}$ with a correlation coefficient, $r=0.9999$. The concentration of phenolics content in the extract was expressed as $\mathrm{mg}$ gallic acid equivalent (GAE)/100 mg dry weight of extract. The flavonoid content of extract was determined using catechin (C) as reference standard. ${ }^{32}$ The sample was mixed with aluminum trichloride solution (10\%) and one drop of acetic acid was added. Then, the mixture was diluted with ethanol. After incubation of reaction mixture for $40 \mathrm{~min}$ at ambient temperature, the mixture was vortexed and absorbance was recorded at $510 \mathrm{~nm}$. The absorbance of blank sample and standard catechin solution were measured under the same condition. The total flavonoids content was calculated from the regression equation $\mathrm{y}=0.00039 \mathrm{x}(r=0.9997)$ obtained by plotting calibration curve of standard catechin and expressed as mg catechin equivalent (CE)/100 mg dry weight of extract.

\section{Lipoidal matters}

The leaves and stems of Breynia distacha J. R. Forst (200 g) were exhaustively extracted by cold maceration $(400 \mathrm{~mL}$, x3, each $48 \mathrm{~h}$ ) with aqueous ethanol (70\%). Th e solvents were evaporated to dryness under reduced pressure at $40^{\circ} \mathrm{C}$ (using a rotary evaporator), yielding $4.5 \mathrm{~g}$ (representing $4.2 \%$ of weight of stems and leaves). Distilled water (200 $\mathrm{mL}$ ) was used to suspend the obtained residue and fractionated with $n$-hexane $(50 \mathrm{~mL} \times 3)$ followed by evaporation of solvent under reduced pressure. 


\section{Saponification of $\mathrm{n}$-hexane extract}

The residue was subjected to saponification by refluxing with $0.5 \mathrm{M}$ alcoholic $\mathrm{KOH}$ in a water bath for $2 \mathrm{~h}^{33}$ After cooling, $50 \mathrm{~mL}$ of water was added, and the solution was extracted with ether. The organic phase was washed with water until it became alkali free and was then dried over anhydrous sodium sulphate. The dried residue was kept in a desiccator for GC/MS analysis.

\section{Preparation of fatty acid methyl esters}

The free fatty acids obtained from saponification were subjected to methylation $\left(\mathrm{MeOH}, 4 \%-5 \%\right.$ dry $\mathrm{H}_{2} \mathrm{SO}_{4}$ ) for 2 hours, extracted with ether. Distilled water was used to wash the combined ether extract to remove acidity. Anhydrous sodium sulphate was used to dry ether extract, followed by evaporation till dryness evaporated and was kept for analysis. ${ }^{33}$

\section{Gas chromatography—mass spectroscopy (GC/MS)}

Analysis using GC/MS was carried out using a Thermo Scientific, Trace GC Ultra / ISQ Single Quadrupole MS and an electron ionization system with energy of $70 \mathrm{eV}$ for the ionization process. For GC of unsaponifiable matter, capillary column ( $30 \mathrm{~m}$ length, $0.32 \mathrm{~mm}$ ID and $0.25 \mu \mathrm{m}$ thickness) packed with TG-5MS (5\% phenyl polysilphenylene siloxane) fused silica was used. The temperature of the oven was programmed at an initial temperature $50^{\circ} \mathrm{C}$ (hold $2 \mathrm{~min}$.) to $150^{\circ} \mathrm{C}$ at an increasing rate of $7{ }^{\circ} \mathrm{C} / \mathrm{min}$. then to $270^{\circ} \mathrm{C}$ at an increasing rate $5^{\circ} \mathrm{C}$ $/ \mathrm{min}$. hold $2 \mathrm{~min}$. then to $310^{\circ} \mathrm{C}$ as a final temperature at an increasing rate of $3.5^{\circ} \mathrm{C} / \mathrm{min}$. hold $10 \mathrm{~min}$. The carrier gas was helium gas and used at a constant flow rate of $1 \mathrm{~mL} / \mathrm{min}$. For GC of saponifiable matter, capillary column (30 m x $0.25 \mathrm{~mm}$ ) packed with $70 \%$ cyanopropylpolysilphenylene siloxane was used. The temperature of the oven was programmed at an initial temperature $80 \mathrm{C}$ increased to $230^{\circ} \mathrm{C}$ by the rate of $3{ }^{\circ} \mathrm{C} / \mathrm{min}$, then kept isothermal for $20 \mathrm{~min}$. The carrier gas was helium gas and used at a constant flow rate of $1.5 \mathrm{~mL} / \mathrm{min}$. The peaks in the chromatogram were identified on the basis of their mass spectra. The constituents were identified by comparison of their spectral fragmentation patterns with those of the available database libraries, Wiley (Wiley International, USA) and NIST (Nat. Inst. St. Technol., USA), and/or published data. ${ }^{34}$ The quantification of all identified components was based on the integration of the area under the peak.

\section{RESULTS}

\section{Antiviral and immunogenic features}

In the view of NDV and AIV endemic infectious diseases, fifteen Euphorbiaceae medicinal plants which are easily available throughout various geographical locations in Egypt were taken up to evaluate their antiviral and immunogenic features against respiratory viral infections. The hydro-alcoholic extract yields (\%), traditional uses, region of collection and vernacular name of the investigated plant were illustrated in Table 1. In addition, protection against NDV and AIV $\mathrm{H} 5 \mathrm{~N} 1$ challenge viruses post vaccination and treatment with the plant extract was assessed (Tables 2 and 3).

The cytotoxic concentration fifty $\left(\mathrm{CC}_{50}\right)$ of the crude hydroalcoholic extract of Breynia distacha J. R. Forst recorded the value of $>200$ and $>300$ for NDV and AIV H5N1, respectively (Table 2). This extract showed antiviral inhibition concentration $\left(\mathrm{IC}_{50}\right)$ values of $\leq 2$ and $\leq 3$ against $\mathrm{NDV}$ and $\mathrm{AIV} \mathrm{H} 5 \mathrm{~N} 1$ and antiviral therapeutic index $\left(\mathrm{CC}_{50} /\right.$ $\mathrm{IC}_{50}$ ) of $100 \%$.The antiviral efficacy was compared with ribavirin, a broad spectrum antiviral drug. The CC50 of ribavirin recorded the value of $>300$ and IC50 value of $\leq 3$ with a TI of $100 \%$. A high HI titer $(6.9 \log 2)$ was recorded in serum of the vaccinated chicks treated with Aleurites moluccana, Jatropha curcas, Ricinus communis, Putranjiva roxburghii with protection percent of 95, 95, 100, and $100 \%$, respectively post NDV challenge (Table 3 ). The HI titer in serum of the vaccinated chicks treated with $P$. roxburghii, Euphorbia mauritanica, Acalypha wilkesiana, Aleurites moluccana, Joannesia princeps and R. communis $(8.1 \log 2,8.0 \log 2,7.9 \log 2,7.9 \log 2,7.9$ $\log 2$, and $7.8 \log 2$, respectively with the same protection percent $(90 \%)$ post AIV challenge (Table 4 ). The serum of the vaccinated chicks treated with $B$. distacha has recorded the highest HI titers $(7.1 \log 2$ and $8.3 \log 2)$ with high protection percents (100 and 90\%) post NDV and AIV H5N1 challenge, respectively (Tables 3 and 4). The results of this investigation show that many of the medicinal plants tested are active against the investigated viruses. However, for some plants, the traditional use doesn't appear to match the results obtained. Table 2-4 show the correlation between traditional use(s) and the viral activity. There is a strong correlation for some plants, e.g, Aleurites moluccana

Table 2: Inhibition concentration fifty in embryonated chicken SPF eggs, cytotoxicity concentration fifty and therapeutic index of some Egyptian plant hydroalcoholic extracts.

\begin{tabular}{|c|c|c|c|c|c|c|c|}
\hline \multirow{2}{*}{$\begin{array}{c}\text { Number of } \\
\text { sample }\end{array}$} & \multirow{2}{*}{ Species } & \multicolumn{2}{|c|}{$\mathrm{CC}_{50}$} & \multicolumn{2}{|c|}{$\mathrm{IC}_{50}$} & \multicolumn{2}{|c|}{ TI (\%) } \\
\hline & & NDV & H5N1 & NDV & AIV H5N1 & NDV & AIV H5 \\
\hline 1 & Acalypha wilkesiana forma tricolors Müll. Arg. & $>300$ & $>300$ & $\leq 7$ & $\leq 7$ & 42.8 & 42.8 \\
\hline 2 & Aleurites moluccana (L.) Willd. & $>500$ & $>500$ & $\leq 8$ & $\leq 8$ & 62.5 & 62.5 \\
\hline 3 & Breynia distacha J. R. Forst. & $>200$ & $>300$ & $\leq 2$ & $\leq 3$ & 100 & 100 \\
\hline 4 & Codiaeum variegatum cv. petra. & $>800$ & $>800$ & $\leq 9$ & $\leq 9$ & 88.8 & 88.8 \\
\hline 5 & Euphorbia abyssinica J.F. Gmel. & $>300$ & $>400$ & $\leq 6$ & $\leq 8$ & 50 & 50 \\
\hline 6 & Euphorbia arguta var. dasycarpa & $>300$ & $>300$ & $\leq 7$ & $\leq 7$ & 42.8 & 42.8 \\
\hline 7 & Euphorbia greenwayi var. greenwayi & $>300$ & $>300$ & $\leq 6$ & $\leq 6$ & 50 & 50 \\
\hline 8 & Euphorbia mauritanica L. & $>800$ & $>800$ & $\leq 9$ & $\leq 9$ & 88.8 & 88.8 \\
\hline 9 & Euphorbia milii F. lutescens & $>500$ & $>500$ & $\leq 8$ & $\leq 8$ & 62.5 & 62.5 \\
\hline 10 & Euphorbia trigona cv. Royal Red & $>700$ & $>700$ & $\leq 8$ & $\leq 8$ & 87.5 & 87.5 \\
\hline 11 & Jatropha curcas L. & $>700$ & $>700$ & $\leq 8$ & $\leq 8$ & 87.5 & 87.5 \\
\hline 12 & Joannesia princeps Vell. B. & $>400$ & $>400$ & $\leq 6$ & $\leq 6$ & 66.6 & 66.6 \\
\hline 13 & Putranjiva roxburghii Wall. & $>800$ & $>800$ & $\leq 9$ & $\leq 9$ & 88.8 & 88.8 \\
\hline 14 & Ricinus communis $\mathrm{L}$. & $>500$ & $>500$ & $\leq 8$ & $\leq 8$ & 62.5 & 62.5 \\
\hline 15 & Synadenium grantii Hook F & $>300$ & $>400$ & $\leq 6$ & $\leq 8$ & 50 & 50 \\
\hline
\end{tabular}

NDV: Newcastle disease virus; AIV H5N1: Avian influenza virus $\mathrm{H}_{5 \mathrm{~N} 1}$; $\mathrm{CC}_{50}$ : Cytotoxicity concentration fifty; IC $_{50}$ The antiviral inhibitory concentration fifty; TI: The therapeutic index. 
Table 3: Titer of hemagglutination inhibition in serum of vaccinated chicks treated with plant samples and protection percent against Newcastle disease virus challenge.

\begin{tabular}{|c|c|c|c|c|c|c|c|c|c|}
\hline & \multirow{2}{*}{ Groups } & \multirow{2}{*}{ HI titer } & \multicolumn{6}{|c|}{ Day post challenge (DPC) } & \multirow{2}{*}{$\begin{array}{l}\text { *Protection } \\
\text { percentage } \%\end{array}$} \\
\hline & & & $1^{\text {st }}$ & $2^{\text {nd }}$ & $3^{\text {rd }}$ & $4^{\text {th }}$ & $5^{\text {th }}$ & $6^{\text {th }}$ & \\
\hline \multirow{15}{*}{$\begin{array}{l}\text { Vaccinated group } \\
\text { (20 chicks/ group) } \\
\text { that received plant } \\
\text { extract }\end{array}$} & $\begin{array}{c}\text { Acalypha wilkesiana forma tricolors } \\
\text { Müll.Arg. }\end{array}$ & $6.5 \log 2$ & $0 / 20$ & $1 / 20$ & $1 / 20$ & $1 / 20$ & $0 / 20$ & $0 / 20$ & 85 \\
\hline & Aleurites moluccana (L.) Willd. & $6.9 \log 2$ & $0 / 20$ & $0 / 20$ & $0 / 20$ & $1 / 20$ & $0 / 20$ & $0 / 20$ & 95 \\
\hline & Breynia distacha J. R. Forst. & $7.1 \log 2$ & $0 / 20$ & $0 / 20$ & $0 / 20$ & $0 / 20$ & $0 / 20$ & $0 / 20$ & 100 \\
\hline & Codiaeum variegatum cv. petra. & $6.7 \log 2$ & $0 / 20$ & $0 / 20$ & $0 / 20$ & $0 / 20$ & $1 / 20$ & $0 / 20$ & 95 \\
\hline & Euphorbia abyssinica J.F. Gmel. & $6.4 \log 2$ & $0 / 20$ & $1 / 20$ & $1 / 20$ & $2 / 20$ & $0 / 20$ & $0 / 20$ & 80 \\
\hline & Euphorbia arguta var. dasycarpa & $6.4 \log 2$ & $0 / 20$ & $2 / 20$ & $1 / 20$ & $1 / 20$ & $0 / 20$ & $0 / 20$ & 80 \\
\hline & Euphorbia greenwayi var. greenwayi & $6.4 \log 2$ & $0 / 20$ & $1 / 20$ & $1 / 20$ & $2 / 20$ & $0 / 20$ & $0 / 20$ & 80 \\
\hline & Euphorbia mauritanica L. & $6.6 \log 2$ & $0 / 20$ & $0 / 20$ & $1 / 20$ & $1 / 20$ & $0 / 20$ & $0 / 20$ & 90 \\
\hline & Euphorbia milii F. lutescens & $6.6 \log 2$ & $0 / 20$ & $0 / 20$ & $1 / 20$ & $0 / 20$ & $1 / 20$ & $0 / 20$ & 90 \\
\hline & Euphorbia trigona cv. Royal Red & $6.5 \log 2$ & $0 / 20$ & $0 / 20$ & $2 / 20$ & $1 / 20$ & $0 / 20$ & $0 / 20$ & 85 \\
\hline & Jatropha curcas L. & $6.9 \log 2$ & $0 / 20$ & $0 / 20$ & $0 / 20$ & $1 / 20$ & $0 / 20$ & $0 / 20$ & 95 \\
\hline & Joannesia princeps Vell. B. & $6.7 \log 2$ & $0 / 20$ & $0 / 20$ & $1 / 20$ & $0 / 20$ & $0 / 20$ & $0 / 20$ & 95 \\
\hline & Putranjiva roxburghii Wall. & $6.9 \log 2$ & $0 / 20$ & $0 / 20$ & $0 / 20$ & $0 / 20$ & $0 / 20$ & $0 / 20$ & 100 \\
\hline & Ricinus communis $\mathrm{L}$. & $6.9 \log 2$ & $0 / 20$ & $0 / 20$ & $0 / 20$ & $0 / 20$ & $0 / 20$ & $0 / 20$ & 100 \\
\hline & Synadenium grantii Hook F. & $6.4 \log 2$ & $0 / 20$ & $1 / 20$ & $1 / 20$ & $2 / 20$ & $0 / 20$ & $0 / 20$ & 80 \\
\hline \multicolumn{2}{|c|}{ Control Vaccinated/Non-treated (20 chicks) } & $6.6 \log 2$ & $0 / 20$ & $0 / 20$ & $0 / 20$ & $1 / 20$ & $0 / 20$ & $1 / 20$ & 90 \\
\hline \multicolumn{2}{|c|}{ Control non-vaccinated/Non-treated (20 chicks) } & - & $0 / 20$ & $0 / 20$ & $5 / 20$ & $6 / 20$ & $6 / 20$ & $3 / 20$ & 0 \\
\hline
\end{tabular}

*Protection percent $=$ number of live birds/ numbers of dead birds $\times 100$

Table 4: Titer of hemagglutination inhibition in serum of vaccinated chicks treated with selected Euphorbiaceae plants and protection percent against avian influenza virus AIV H5N1 challenge.

\begin{tabular}{|c|c|c|c|c|c|c|c|c|c|c|c|c|c|}
\hline \multirow{2}{*}{\multicolumn{2}{|c|}{ Groups }} & \multirow{2}{*}{ HI titer } & \multicolumn{10}{|c|}{ Day post challenge (DPC) } & \multirow{2}{*}{$\begin{array}{l}\text { Protection } \\
\text { percent }\end{array}$} \\
\hline & & & $1^{\text {st }}$ & $2^{\text {nd }}$ & $3^{\text {rd }}$ & $4^{\text {th }}$ & $5^{\text {th }}$ & $6^{\text {th }}$ & $7^{\text {th }}$ & $8^{\text {th }}$ & $9^{\text {th }}$ & $10^{\text {th }}$ & \\
\hline \multirow{15}{*}{$\begin{array}{l}\text { Vaccinated } \\
\text { group of chicks } \\
\text { ( } 20 \text { chicks/ } \\
\text { group) that } \\
\text { received plant } \\
\text { extract }\end{array}$} & $\begin{array}{c}\text { Acalypha wilkesiana } \\
\text { forma tricolors Müll. } \\
\text { Arg. }\end{array}$ & $7.9 \log 2$ & $0 / 20$ & $0 / 20$ & $0 / 20$ & $1 / 20$ & $0 / 20$ & $1 / 20$ & $0 / 20$ & $0 / 20$ & $0 / 20$ & $0 / 20$ & $90 \%$ \\
\hline & $\begin{array}{l}\text { Aleurites moluccana } \\
\text { (L.) Willd. }\end{array}$ & $7.9 \log 2$ & $0 / 20$ & $0 / 20$ & $2 / 20$ & $0 / 20$ & $0 / 20$ & $0 / 20$ & $0 / 20$ & $0 / 20$ & $0 / 20$ & $0 / 20$ & $90 \%$ \\
\hline & $\begin{array}{l}\text { Breynia distacha J. R. } \\
\text { Forst }\end{array}$ & $8.3 \log 2$ & $0 / 20$ & $0 / 20$ & $2 / 20$ & $0 / 20$ & $0 / 20$ & $0 / 20$ & $0 / 20$ & $0 / 20$ & $0 / 20$ & $0 / 20$ & $90 \%$ \\
\hline & $\begin{array}{l}\text { Codiaeum variegatum } \\
\text { cv. petra }\end{array}$ & $7.6 \log 2$ & $0 / 20$ & $0 / 20$ & $2 / 20$ & $1 / 20$ & $0 / 20$ & $0 / 20$ & $0 / 20$ & $0 / 20$ & $0 / 20$ & $0 / 20$ & $85 \%$ \\
\hline & $\begin{array}{c}\text { Euphorbia } \\
\text { abyssinica J.F. Gmel. }\end{array}$ & $7.1 \log 2$ & $0 / 20$ & $0 / 20$ & $0 / 20$ & $1 / 20$ & $0 / 20$ & $1 / 20$ & $2 / 20$ & $1 / 20$ & $1 / 20$ & $0 / 20$ & $80 \%$ \\
\hline & $\begin{array}{c}\text { Euphorbia arguta var. } \\
\text { dasycarpa }\end{array}$ & $8.0 \log 2$ & $0 / 20$ & $0 / 20$ & $2 / 20$ & $0 / 20$ & $0 / 20$ & $0 / 20$ & $0 / 20$ & $0 / 20$ & $0 / 20$ & $0 / 20$ & $90 \%$ \\
\hline & $\begin{array}{l}\text { Euphorbia greenwayi } \\
\text { var. greenwayi }\end{array}$ & $7.4 \log 2$ & $0 / 20$ & $1 / 20$ & $1 / 20$ & $2 / 20$ & $0 / 20$ & $0 / 20$ & $0 / 20$ & $0 / 20$ & $0 / 20$ & $0 / 20$ & $80 \%$ \\
\hline & $\begin{array}{l}\text { Euphorbia } \\
\text { mauritanica L. }\end{array}$ & $7.4 \log 2$ & $0 / 20$ & $0 / 20$ & $2 / 20$ & $0 / 20$ & $0 / 20$ & $2 / 20$ & $0 / 20$ & $0 / 20$ & $0 / 20$ & $0 / 20$ & $80 \%$ \\
\hline & $\begin{array}{c}\text { Euphorbia milii } \mathrm{F} . \\
\text { lutescens }\end{array}$ & $7.5 \log 2$ & $0 / 20$ & $2 / 20$ & $0 / 20$ & $2 / 20$ & $0 / 20$ & $0 / 20$ & $0 / 20$ & $0 / 20$ & $0 / 20$ & $0 / 20$ & $80 \%$ \\
\hline & $\begin{array}{c}\text { Euphorbia trigona cv. } \\
\text { Royal Red }\end{array}$ & $7.4 \log 2$ & $0 / 20$ & $0 / 20$ & $2 / 20$ & $0 / 20$ & $0 / 20$ & $2 / 20$ & $0 / 20$ & $0 / 20$ & $0 / 20$ & $0 / 20$ & $80 \%$ \\
\hline & Jatropha curcas L. & $7.5 \log 2$ & $0 / 20$ & $1 / 20$ & $0 / 20$ & $1 / 20$ & $1 / 20$ & $0 / 20$ & $0 / 20$ & $0 / 20$ & $0 / 20$ & $0 / 20$ & $85 \%$ \\
\hline & $\begin{array}{l}\text { Joannesia princepsVell. } \\
\text { B. }\end{array}$ & $7.9 \log 2$ & $0 / 20$ & $0 / 20$ & $1 / 20$ & $0 / 20$ & $1 / 20$ & $0 / 20$ & $0 / 20$ & $0 / 20$ & $0 / 20$ & $0 / 20$ & $90 \%$ \\
\hline & $\begin{array}{l}\text { Putranjiva roxburghii } \\
\text { Wall. }\end{array}$ & $8.1 \log 2$ & $0 / 20$ & $0 / 20$ & $1 / 20$ & $1 / 20$ & $0 / 20$ & $0 / 20$ & $0 / 20$ & $0 / 20$ & $0 / 20$ & $0 / 20$ & $90 \%$ \\
\hline & Ricinus communis L. & $7.8 \log 2$ & $0 / 20$ & $0 / 20$ & $1 / 20$ & $0 / 20$ & $1 / 20$ & $0 / 20$ & $0 / 20$ & $0 / 20$ & $0 / 20$ & $0 / 20$ & $90 \%$ \\
\hline & $\begin{array}{l}\text { Synadenium grantii } \\
\text { Hook F. }\end{array}$ & $7.5 \log 2$ & $0 / 20$ & $0 / 20$ & $1 / 20$ & $2 / 20$ & $0 / 20$ & $0 / 20$ & $0 / 20$ & $0 / 20$ & $0 / 20$ & $0 / 20$ & $85 \%$ \\
\hline \multicolumn{2}{|c|}{$\begin{array}{l}\text { Control Vaccinated/Non-treated (20 } \\
\text { chicks) }\end{array}$} & $7.1 \log 2$ & $0 / 20$ & $0 / 20$ & $0 / 20$ & $1 / 20$ & $0 / 20$ & $1 / 20$ & $2 / 20$ & $1 / 20$ & $1 / 20$ & $0 / 20$ & $80 \%$ \\
\hline \multicolumn{2}{|c|}{$\begin{array}{c}\text { Control non-vaccinated/Non-treated } \\
\text { (20 chicks) }\end{array}$} & & $0 / 20$ & $0 / 20$ & $5 / 20$ & $6 / 20$ & $6 / 20$ & $3 / 20$ & $0 / 20$ & $0 / 20$ & $0 / 20$ & $0 / 20$ & $0 \%$ \\
\hline
\end{tabular}

HI titer: hemagglutination inhibition titer; Protection percent of the vaccine $=$ number of live birds/ numbers of dead birds $\times 100$ 
(L.) Willd., Breynia distacha J. R. Forst., Jatropha curcas L., Ricinus communis L., and Putranjiva roxburghii Wall. For other plants, the correlation seems less obvious.

\section{Chemical composition of Breynia distacha J. R. Forst}

\section{Total polyphenolic and flavonoid contents}

The active extract was further subjected to estimation of total polyphenolic and flavonoid contents using Folin-Ciocalteu reagent and aluminum chloride colorimetric assay methods, respectively. Spectrophotometric determination of total phenolics and flavonoids content of $B$. distacha J. R. Forst hydroalcoholic extract were determined using equivalents to gallic acid and catechin, respectively. Results showed that $18.53 \pm 1.24 \mu \mathrm{g}$ of gallic acid were equivalent to $1 \mathrm{~g}$ of dry weight. The total flavonoids content determination by aluminum chloride method was $7.32 \pm 0.09 \mu \mathrm{g}$ catechin were equivalent to $1 \mathrm{~g}$ dry weight.

\section{Lipoidal matters}

The solvent-free residue obtained by the saponification of $\boldsymbol{n}$-hexane extract was represented the unsaponifiable matters (USM). It was an orange-yellow in color and amounted to $0.42 \mathrm{~g}$ calculated as $79.8 \%$ of the total lipoidal composition of the corresponding $n$-hexane extract. The saponifiable matters was obtained as oily residue $(0.040 \mathrm{~g})$ calculated as $16.6 \%$ of the total lipoidal composition of the corresponding $n$-hexane extract. Identification of saponifiable and unsaponifiable components using GC/MS technique was carried out (Table 5). GC/MS analysis allowed identification of $91.10 \%$ of the total unsaponifiable matter, (1-heptatriacotanol represented the major component, $24.61 \%$ ) and $82.51 \%$ of the fatty acid methyl ester content (methyl palmitate represented the major component, 26.13 $\%)$. Thirty-one compounds were identified (Table 5) by GC/MS of unsaponifiable matter, representing $91.10 \%$ of its total content. The identified components comprise $23.24 \%$ unoxygenated compounds and $39.62 \%$ oxygenated compounds, and $28.24 \%$ steroidal/triterpenoidal compounds. Results in table 5 show that two hydrocarbons represented the major constituents (1-heptatriacotanol $\mathrm{C}_{37} \mathrm{H}_{76} \mathrm{O}, 24.61 \%$ and dotriacontane $\left.\mathrm{C}_{32} \mathrm{H}_{66}, 13.74 \%\right)$. $\beta$-Sitosterol $\mathrm{C}_{29} \mathrm{H}_{50} \mathrm{O}$ (11.92\%) was the abundant plant sterol detected by GC/MS in unsaponifiable part. Among the phytosterols namely campesterol $\mathrm{C}_{28} \mathrm{H}_{48} \mathrm{O}$ and stigmasterol $\mathrm{C}_{29} \mathrm{H}_{48} \mathrm{O}$ were identified in minor levels and constituted 1.38 and $3.03 \%$, respectively. Phytosterol accounted $16.33 \%$ of the total unsaponifiable fraction. On the other hand, volatile monoterpenes and hydrocarbons were identified in traces levels as well as the triterpene $\alpha$-amyrin. Fifteen fatty acid methyl esters were identified, representing $82.51 \%$ of the total saponifiable matter (Table 6).

Methyl palmitate $\mathrm{C}_{18} \mathrm{H}_{36} \mathrm{O}_{2}$ and methyl linolenate $\mathrm{C}_{19} \mathrm{H}_{32} \mathrm{O}_{2}$ represented the major components (26.13 and $15.82 \%$, respectively). Saturated fatty acids represent $54.49 \%$ of the total fatty acid content, whereas monounsaturated, diunsaturated, and triunsaturated fatty acids represent by $7.78,4.41$ and, and $15.82 \%$ of the total fatty acid content, respectively. Eight were identified as methyl esters unsaturated fatty

\section{Table 5. GC/MS analysis of unsaponifiable matter from Breynia distacha J. R. Forst aerial parts.}

\begin{tabular}{|c|c|c|c|c|}
\hline Peak & $R_{t}$ & Name & Formula & Area Sum \% \\
\hline 1 & 18.07 & Isooctylvinyl Ether & $\mathrm{C}_{10} \mathrm{H}_{20} \mathrm{O}$ & 0.28 \\
\hline 2 & 18.62 & 6-Octen-1-ol, 3,7-dimethyl & $\mathrm{C}_{10} \mathrm{H}_{20} \mathrm{O}$ & 0.41 \\
\hline 3 & 19.95 & 1-Nonanol & $\mathrm{C}_{9} \mathrm{H}_{20} \mathrm{O}$ & 0.65 \\
\hline 4 & 21.91 & Tridecanol & $\mathrm{C}_{13} \mathrm{H}_{28} \mathrm{O}$ & 0.46 \\
\hline 5 & 22.32 & 5-Isopropyl-3,3,-dimethyl-2- methylene-2,3-dihydrofuran & $\mathrm{C}_{10} \mathrm{H}_{16} \mathrm{O}$ & 0.84 \\
\hline 6 & 22.46 & Docosane & $\mathrm{C}_{22} \mathrm{H}_{46}$ & 0.51 \\
\hline 7 & 22.58 & 4,8,12,16-Tetramethylheptadecan-4-olide & $\mathrm{C}_{21} \mathrm{H}_{40} \mathrm{O}_{2}$ & 0.49 \\
\hline 8 & 22.84 & Methyl 5-hydroxy-5-methyl-5,6,7,8-tetrahydronaphthalene-1-carboxylate & $\mathrm{C}_{13} \mathrm{H}_{16} \mathrm{O}_{3}$ & 0.25 \\
\hline 9 & 23.08 & 6,10,14-Trimethyl-pentadecan-2-one & $\mathrm{C}_{18} \mathrm{H}_{36} \mathrm{O}$ & 0.28 \\
\hline 10 & 23.37 & 17-Pentatriacontene & $\mathrm{C}_{35} \mathrm{H}_{7} \mathrm{O}$ & 1.07 \\
\hline 11 & 23.48 & 9,19-Cyclolanost-24-en-3-ol, acetate, $(3-\beta)$ - & $\mathrm{C}_{32} \mathrm{H}_{52} \mathrm{O} 2$ & 2.19 \\
\hline 12 & 24.14 & 2,2,4,9,11,11-Hexamethyldodecane & $\mathrm{C}_{18} \mathrm{H}_{38}$ & 5.90 \\
\hline 13 & 24.27 & 6,10-Dimethylundecan-2-one & $\mathrm{C}_{13} \mathrm{H}_{26} \mathrm{O}$ & 0.31 \\
\hline 14 & 24.51 & 9- $n$-Dodecylperhydrophenanthrene & $\mathrm{C}_{26} \mathrm{H}_{48}$ & 1.85 \\
\hline 15 & 24.64 & 2-Methyl-hexadecanal & $\mathrm{C}_{17} \mathrm{H}_{34} \mathrm{O}$ & 0.55 \\
\hline 16 & 25.04 & Quercetin 7,3',4'-trimethoxy & $\mathrm{C}_{18} \mathrm{H}_{16} \mathrm{O}_{7}$ & 0.74 \\
\hline 17 & 25.33 & Heneicosane & $\mathrm{C}_{21} \mathrm{H}_{44}$ & 0.34 \\
\hline 18 & 26.85 & Heptacosane & $\mathrm{C}_{27} \mathrm{H}_{56}$ & 0.90 \\
\hline 19 & 27.03 & $(3 \beta, 15 \alpha, 16 \alpha, 21 \beta, 22 \alpha)$-Olean-12-ene-3,15,16,21,22,28-hexol & $\mathrm{C}_{30} \mathrm{H}_{50} \mathrm{O}_{6}$ & 1.08 \\
\hline 20 & 27.78 & Betulin & $\mathrm{C}_{30} \mathrm{H}_{50} \mathrm{O}_{2}$ & 4.48 \\
\hline 21 & 28.12 & Dihydroxanthin & $\mathrm{C}_{17} \mathrm{H}_{24} \mathrm{O}_{5}$ & 0.93 \\
\hline 22 & 28.60 & 4,4-Dimethyl-3-oxacholest-5-en-7-one & $\mathrm{C}_{28} \mathrm{H}_{46} \mathrm{O}_{2}$ & 2.38 \\
\hline 23 & 29.07 & Lanosta-8,24-dien-3-ol & $\mathrm{C}_{30} \mathrm{H}_{50} \mathrm{O}$ & 1.08 \\
\hline 24 & 29.30 & Dotriacontane & $\mathrm{C}_{32} \mathrm{H}_{66}$ & 13.74 \\
\hline 25 & 29.84 & Stigmast,3,5-diene-7-one & $\mathrm{C}_{29} \mathrm{H}_{46} \mathrm{O}$ & 6.55 \\
\hline 26 & 30.35 & 1-Heptatriacotanol & $\mathrm{C}_{37} \mathrm{H}_{76} \mathrm{O}$ & 24.61 \\
\hline 27 & 31.29 & a-Amyrin & $\mathrm{C}_{30} \mathrm{H}_{50} \mathrm{O}$ & 1.90 \\
\hline 29 & 32.02 & Campesterol & $\mathrm{C}_{28} \mathrm{H}_{48} \mathrm{O}$ & 1.38 \\
\hline 30 & 32.24 & Stigmasterol & $\mathrm{C}_{29} \mathrm{H}_{48} \mathrm{O}$ & 3.03 \\
\hline 31 & 33.92 & $\beta$-Sitosterol & $\mathrm{C}_{29} \mathrm{H}_{50} \mathrm{O}$ & 11.92 \\
\hline
\end{tabular}

GC/MS, gas chromatograph coupled with a mass spectrometer; $R_{t}$ : Retention time. 
Table 6: GC/MS analysis of fatty acids methyl esters from Breynia distacha J. R. Forst aerial parts.

\begin{tabular}{|c|c|c|c|c|}
\hline Peak & Rt & Name & Formula & Area $\%$ \\
\hline 1 & 11.02 & Methyl dodecanoate (Dodecanoic acid methyl ester) & $\mathrm{C}_{13} \mathrm{H}_{26} \mathrm{O}_{2}$ & 0.23 \\
\hline 2 & 11.84 & Methyl tetradecanoate (Tetradecanoic acid methyl ester) & $\mathrm{C}_{15} \mathrm{H}_{30} \mathrm{O}_{2}$ & 0.38 \\
\hline 3 & 13.88 & Methyl pentadecanoate (Pentadecanoic acid methyl ester) & $\mathrm{C}_{16} \mathrm{H}_{32} \mathrm{O}_{2}$ & 2.35 \\
\hline 4 & 17.89 & Methyl 13-methyltetradecanoate & $\mathrm{C}_{16} \mathrm{H}_{32} \mathrm{O}_{2}$ & 0.78 \\
\hline 5 & 18.09 & Ethyl 9-tetradecenoate & $\mathrm{C}_{16} \mathrm{H}_{30} \mathrm{O}_{2}$ & 0.65 \\
\hline 6 & 18.59 & Methyl isohexadecanoate & $\mathrm{C}_{17} \mathrm{H}_{34} \mathrm{O}_{2}$ & 1.63 \\
\hline 7 & 18.77 & Methyl palmitoleate (9-Hexadecenoic acid methyl ester) & $\mathrm{C}_{17} \mathrm{H}_{32} \mathrm{O}_{2}$ & 0.62 \\
\hline 8 & 23.75 & Methyl palmitate (Hexadecanoic acid methyl ester) & $\mathrm{C}_{18} \mathrm{H}_{36} \mathrm{O}_{2}$ & 26.13 \\
\hline 9 & 25.49 & Methyl elaidate (9-Octadecenoic acid, methyl ester) & $\mathrm{C}_{19} \mathrm{H}_{36} \mathrm{O}_{2}$ & 1.62 \\
\hline 10 & 26.12 & Methyl (E)-octadec-12-enoate & $\mathrm{C}_{19} \mathrm{H}_{36} \mathrm{O}_{2}$ & 4.44 \\
\hline 11 & 28.45 & Methyl (8E,11E)-8,11-octadecadienoate & $\mathrm{C}_{19} \mathrm{H}_{34} \mathrm{O}_{2}$ & 4.41 \\
\hline 12 & 29.06 & Methyl linolenate (Methyl octadeca-9,12,15-trienoate) & $\mathrm{C}_{19} \mathrm{H}_{32} \mathrm{O}_{2}$ & 15.82 \\
\hline 13 & 29.25 & Ethyl octadeca-9,12-dienoate (Linolelaidic acid ethyl ester) & $\mathrm{C}_{20} \mathrm{H}_{36} \mathrm{O}_{2}$ & 3.91 \\
\hline 14 & 30.38 & Ethyl stearate (Ethyl octadecenoate) & $\mathrm{C}_{20} \mathrm{H}_{40} \mathrm{O}_{2}$ & 8.65 \\
\hline 15 & 31.96 & Methyl (Z)-icos-11-enoate & $\mathrm{C}_{21} \mathrm{H}_{40} \mathrm{O}_{2}$ & 0.45 \\
\hline 16 & 33.25 & 30-Norlupan-28-oic acid, 3-hydroxy-21-methoxy-20-oxo-, methyl ester, (3ß)- & $\mathrm{C}_{31} \mathrm{H}_{50} \mathrm{O}_{5}$ & 10.44 \\
\hline
\end{tabular}

GC/MS, gas chromatograph coupled with a mass spectrometer; Rt: Retention time.

acids $(28.01 \%)$. Methyl palmitate was the major saturated fatty acid (26.13\%) followed by 30-norlupan-28-oic acid, 3-hydroxy-21-methoxy20-oxo-, methyl ester, (3 $\beta)$ - (10.44\%). While, methyl linolenate (methyl octadeca-9,12,15-trienoate was the predominant unsaturated fatty acid (15.82\%). Methyl (8E,11E)-8,11-octadecadienoate (C19:2) and methyl octadeca-9,12,15-trienoate, C19:3) were represented the diunsaturated and triunsaturated fatty acids (4.41 and $15.82 \%)$, respectively.

\section{DISCUSSION}

The study concerns the use of fifteen selected plants belong to family of Euphorbiaceae (Table 1) to combat emerging infectious poultry diseases. These selected plants are widely distributed and easily available throughout various geographical locations in Egypt (Table 1). These plants having a history of use in Egyptian traditional medicine for the treatment of infectious disease (Table 1). They were investigated for antiviral activity against respiratory tract infection pathogens (NDV and AIV) in SPF chicken embryos.

NDV and AIV of the H5N1 subtype viruses are the main respiratory causes of high mortality rates in poultry. They are highly pathogenic to poultry and humans. In Egypt, poultry industry faced severe outbreaks due to mixed infections of these viruses which were causing high mortality and great economic losses. In the recent years, co-infections with these viral diseases have taken a serious toll on the production of poultry products. ${ }^{4}$ The increase in infectious disease and the prevalent resistance of microorganisms to antibiotics and antiviral agents, urges us to search for new medicinal products which are novel and more efficient. Among the control measures, existing vaccines are unable to keep up with the mutation rates of viruses. New vaccine development takes a long time and at the same time, viruses are also developing resistance to the currently used drugs. ${ }^{46}$ Hence, there is no immediate response drug to the newly emerging virus infections/outbreaks. To address this problem, there is an exigent need for the development of a new paradigm preventive and therapeutic agent to control the immediate spread of viral outbreaks.

Traditional herbal medicines have been postulated to prove effective sources of valuable potential medicines due to fewer side effects, relatively low cost and easy availability. The local flora has been traditionally used in many cultures as a source of medicine ${ }^{46}$ It has been documented that a great amount of traditional knowledge about the uses of medicinal plant species is still carried and orally transmitted by indigenous peoples. ${ }^{35}$ Many workers have therefore chosen the ethnobotanical approach as a means of focusing on plants with pharmacologically active agents of potential therapeutic interest. ${ }^{36}$ The documentation of traditional knowledge especially on the medicinal uses of plants has provided many important drugs of modern day. ${ }^{35,36}$ This principle has been shown to work efficiently in screening for antivirals, where a high percentage of positive results have been obtained..$^{27}$ In many parts of the world, ethnoveterinary medicine is frequently used to treat and to control animal diseases in livestock and poultry by the breeders because it is easily accessible compared to conventional drugs, easy to prepare and administer, and cost very little or nothing at all. ${ }^{37}$ In many countries including Egypt, scientific studies and documentation of indigenous knowledge on ethnoveterinary medicinal plants have been initiated. In addition, considering the cases of resistance to the conventional drug used around the world. ${ }^{9}$ It is necessary to resort the medicinal plants use by breeders in livestock. These remedies were mostly administered as decoctions or infusions of single plants. These plants were used not only as alternatives to conventional veterinary drugs but also because in certain diseases they were thought to be more efficacious.

According to the observed folkloric uses of the family Euphorbiaceae it received a distinctive phytochemical investigation which revealed the presence of diverse metabolites such as polyphenols. ${ }^{39}$ Polyphenols are secondary plant metabolites which have been shown to exert antioxidative and anti-inflammatory effects that are related with the animal health and performance. Activity of different polyphenolic compounds in plants worked their best when added to the cells just around or before the time of virus adsorption using in vitro model. ${ }^{40}$ They do possess high binding affinities with viral hemagglutination which might be a reason for their prophylactic activity. Since these extracts shows no adverse effect, a clinical pilot study would give further information on the potency of these extracts in protecting against respiratory virus infection in chickens. Polyphenolic compounds are very well-known plant constituents because of their scavenging ability. ${ }^{41}$ It is demonstrated that polyphenolic compounds possess inhibitory effects against viral infection. Phytochemical components, especially these polyphenols (such as flavonoids, tannins, phyenyl propanoids, phenolic acids etc) are known to be responsible for the free radical scavenging and antioxidant activities. In our present study, a flavonoid (7,3',4'-trimethoxy quercetin) was identified using GC/MS analysis of Breynia distacha. Flavonoids such as quercetin and its derivatives are important plant-derived polyphenolic compounds and have beneficial to reduce the viral genome replication, the production of infectious hepatitis $C$ virus particles, and the specific infectivity of the newly produced viral particles. ${ }^{42}$ 
Breynia distacha J. R. Forst is a rounded ornamental shrub traditional medicine in the treatment of malaria and reports of its in vivo antimalarial activities have been published. ${ }^{41}$ The serum of the vaccinated chicks treated with Breynia distacha J. R. Forst. has recorded the highest HI titers $(7.1 \log 2$ and $8.3 \log 2)$ with high protection percents (100 and 90\%) post NDV and AIV H5N1 challenge, respectively. The plant is a tropical shrub widely grown in tropical Africa and is used as chewing stick and the treatment of fever and malaria in Nigeria. The leaves have characteristic green, purple and pink color, found in gardens and public areas. Few studies have been published regarding the phytochemistry and biological activity of this plant. Amide derivatives, dioxopiperazine derivatives and acylated hydroquinone such as apiofuranosyl glucopyranoside was isolated from the B. distacha J. R. Forst. A hydroxyanthraquinone analogue, mitoxantrone, was known to be inhibitor of hepatitis C virus NS3 helicase. ${ }^{43}$ The quercetin and kaempferol derivatives isolated from the plant species were showed to have significant antioxidant activity. Findings from our study confirm what other studies have found with the antiviral activities of the isolated compounds from this species including the kaempferol and its derivative; kaempferol 8-methyl ether as well as the quercetin derivative; quercetin 3-methyl ether. ${ }^{35}$ Other compounds breynioside A, asperphenamate, robustaside A (E)- $p$-coumaric acid, cristatin A, blumenol A and lygodinolide were also identified in the plant leaves.

The active extract $B$. distach $a$ J. R. Forst was subjected to estimation of total polyphenolic and flavonoid contents using Folin-Ciocalteu reagent and aluminum chloride colorimetric assay methods, respectively. Results showed that $18.53 \pm 1.24 \mu \mathrm{g}$ of gallic acid were equivalent to $1 \mathrm{~g}$ of dry weight. The total flavonoids content determination by aluminum chloride method was $7.32 \pm 0.09 \mu \mathrm{g}$ catechin were equivalent to $\mathrm{lg}$ dry weight. The finding of our study could indicate $B$. distacha as immunostimulant has special immune boosting properties as it elevates the antibody titer in serum of the vaccinated chicks. The polyphenolics and flavonoids of this plant could act as antioxidants and may therefore enhance the immune function.

Herbal plant polyphenolics and flavonoids also have been extensively studied for immunomodulatory effects as they could considerably improve the antibody titer in vaccinated chicken. The immunostimulating activities of many of these components have been most widely studied in chicken and human cell lines. ${ }^{18}$ Embryonated eggs inoculated with a mixture of NDV or AIV H5N1 with each sample separately affect the virus titer (Tables 3 and 4 ).

GC/MS analysis of both unsaponifiable matter and fatty acids allowed identification of $91.10 \%$ of the total unsaponifiable matter, (1-heptatriacotanol represented the major component, 24.61\%) and $82.51 \%$ of the fatty acid methyl ester content (methyl palmitate represented the major component, $26.13 \%$ ). In our present study, $3 \beta$-Hydroxy-21-methoxy-20-oxo-30-norlupan-28-oic acid methyl ester was identified (10.44\%). Lupane derivatives and of some 30-norlupan derivative were suggested as potential influenza virus entry inhibitors. ${ }^{44}$ Recently, Zhou et al (2019) ${ }^{46}$ has isolated a triterpenoid norlupan derivative (20S-17 $\beta, 29$-epoxy-28-norlupan-3 $\beta$-ol) from the ethyl acetate soluble portion of the EtOH extract of Leonurus japonicus, the plant with potent antibacterial activity. Carotenoids like dihydroxanthin was also found in small amounts with $(0.46 \%)$. Another identified compound hexadecanoic acid, methyl ester (methyl palmitate) was reported with various activities including the antioxidant, antibacterial and antifungal. ${ }^{44}$

The genus Euphorbia is the largest genus of medicinal plants widely distributed in tropical countries and is one of the most diverse groups of flowering plants on earth. The genus comprises over 2000 species worldwide and its global distribution includes more than 750 species in Africa and 42 indigenous to Egypt. Some species of Euphorbia have been traditionally used for the treatment of skin diseases, gonorrhea and as wart cures. The leaves of E. hirta are used to make a decoction that believe to alleviate viral infection and associated fever symptoms. During the field survey in Benin, 57 plant species of ethnopharmacological importance, Euphorbia unispina and E. poissonii were reported as the common plants used to treat viral disease against major viral diseases as African swine fever, pseudo-rinderpest and foot/ mouth disease. ${ }^{37}$ The macerated whole plant of E. unispina N.E.Br. and the stems of E. poissonii Pax. were used orally once a day for one week as remedies used for the treatment of Newcastle disease among village chickens of South Western Uganda and Benin. E. unispina was most reported by the breeders to control other animal's viral ailments. ${ }^{37}$

The immune system provides protection against infectious diseases that are caused by various microorganisms including viruses. ${ }^{3}$ Viral infections are one of the most transmissible diseases in the world. In poultry production, it is very important to improve immunity so as to prevent infectious diseases. Utilization of immunostimulants is one solution to improve the immunity of animals and to decrease their susceptibility to infectious diseases. ${ }^{18}$ The use of plant products as immunostimulants has a traditional history. Emerging evidence indicates that herbal remedies and/or natural products exert their beneficial effects on animal immune system mostly by plant secondary metabolites. ${ }^{18}$ Metabolites have various functions and medicinal plants are valuable source of a wide range of primary and secondary type, which are used as pharmaceuticals and they have immune-stimulating properties including macrophage activation and lymphocyte activity. ${ }^{18}$ Crude plant extracts often consist of complex mixtures of active primary and secondary metabolites, they may show greater overall bioactivity compared to the individual constituents. ${ }^{9}$ A large number of small molecules, like phenolics, polyphenols, terpenes, flavonoids, and sugar from plants have been reported to be effective against influenza type A and B respiratory viruses such as Elderberry liquid extract from Sambucus nigra, extracts from Pelargonium sidoides roots, Gentian root, Primula flower, Elder flower, Sorrel herb, and Verbena herb. ${ }^{46}$

Several secondary metabolites from the Euphorbia genus exhibited antiviral activity against HIV, HSV, and Epstein-Barr virus. ${ }^{47}$ Flavonoids, steroidal glycoside, alkaloids, proanthocyanidin, saponins, terpenes, polysaccharides, quinones, lignans, tannins, thiosulfinates are metabolites with claimed immunomodulatory and antiviral properties. A commercial formulation (capsule) has been developed and the local communities in the Philippines consume E. hirta as a treatment for dengue, a viral disease. ${ }^{47}$ Flu-like symptoms were markedly reduced following this species treatment which was attributed to its antiinflammatory and immunomodulatory properties. The antiretroviral activities this plant extract against HIV-1, HIV-2 and SIVmac251. ${ }^{19,47}$ The hydroalcoholic extract was found to exert a higher antiretroviral effect than that of the aqueous extract. ${ }^{47}$ The dichloromethane-methanol extract of E. tirucalli latex has showed $81 \%$ defense against tobacco mosaic virus at 150 ppm..$^{9,19}$ In the current study, six species of genus Euphorbia have been studied for their immune boosting properties and combating of multiple respiratory viral infections in poultry. In our study the antiviral efficacy was determined in term of reduction in viral titers measured by the hemagglutination inhibition (HI) assay. Hemagglutination is the aggregation of red blood cells (RBCs) in suspension in the presence of certain (hemagglutinating) virus particles. This phenomenon is a result of attachment of specific outer viral peplomeres (hemagglutinins) with specific receptors present on the surface of RBCs. This characteristic feature can be used in detection of the virus. Inhibition of hemagglutination caused by these viruses is the detection of their activity's inhibition. In each case of the tested samples; the toxicity assays in embryonated chicken SPF eggs indicated that at concentration $\left(\mathrm{CC}_{50}\right)$ ranging from $200-800 \mu \mathrm{L} /$ egg (Table 1). 
The HI titer were $7.1 \log 2,8.0 \log 2,7.4 \log 2,7.4 \log 2,7.5 \log 2,7.4 \log 2$ in the serum in the serum of the vaccinated chicks treated with Euphorbia abyssinica, E. arguta var. dasycarpa, E. greenwayi, E. mauritanica, E. milii $\mathrm{F}$. lutescens, and $E$. trigona, respectively with protection percentage of $80 \%$ post AIV H5N1 challenge for all species except Euphorbia milii F. lutescens (90\%). Euphorbia milii, a flowering plant commonly known as "Christ plant" or "Christ thrown". It has been reported that E. milii possesses antifungal and antinociceptive property, acts as natural molluscicide. ${ }^{19}$ Phytochemical studies of this plant revealed the presence of $\beta$-sitosterol, cycloartenol, $\beta$-amyrin acetate, lupeol, euphol, triterpenes, phenols and flavonoids. Euphorbia mauritanica extract is poorly discussed in literature. The plant was reported to induce antiproliferative activities in lung cancer cells and has an anti-inflammatory effect on primary human dermal fibroblasts. ${ }^{17}$ The findings of our study recorded the antiviral activity of this plant for the first time. E. trigona has remarkable anti-swarming properties against Proteus mirabilis and Pseudomonas aeruginosa. ${ }^{16}$

Phytochemicals with significance antioxidant and immunomodulatory abilities were reported. The tripernoids and flavonoids of Euphorbia genus were useful to have immuno-boosting properties and inhibit virus replication. Betulin, a triterpenoid was identified in our study (4.48\%) in unsaponifiable matter from Breynia distacha J. R. Forst aerial parts using GC/MS analysis. This compound was previously isolated from the aerial parts of E. spinidens and recorded immunomodulatory activity and has shown encouraging stimulatory effect on the proliferation of human peripheral blood lymphocytes activated by PHA. In our current study, E. abyssinica, E. arguta var. dasycarpa and E. greenwayi were light active post-NDV challenge with protection percentage of $80 \%$. The leaves methanol extract of E. helioscopia which was administered to chicken embryos through chorioallantoic membrane has showed no malformation confirm the safety of this extract at in pregnancy at therapeutic dose. ${ }^{47}$ The extract at $0.75 \mathrm{mg} / \mathrm{mL}$ inhibited phage growth and reproduction more than $50 \%$ and showed potential antiviral activity using bacteriophage CP51.

In the current study, the HI titer in serum of the vaccinated chicks treated with P. roxburghii, Euphorbia mauritanica, Acalypha wilkesiana Müll. Arg., Aleurites moluccana (L.) Willd, Joannesia princeps Vell. B and $R$. communis $(8.1 \log 2,8.0 \log 2,7.9 \log 2,7.9 \log 2,7.9 \log 2$, and $7.8 \log 2$, respectively with the same protection percent $(90 \%)$ post AIV challenge. The leaves $P$. roxburghii Wall are normally procreant, bitter, refrigerant and astringent. It was concluded that the plant has potential antiviral activity, confirming the popular use. It has long been used in folkloric medicine for treating arthralgia, fever, hemorrhoids, muscle pain and also helpful in curing rheumatism. ${ }^{23}$ P. roxburghii plays an important, assuring role in the traditional medical systems of Unani and Ayurvedic. It has been used for many conventional health applications such as treatment of mouth and stomach ulcers, hot swellings and small pox. Antifungal result showed higher value for Trychorphyton rubrum was reported. P. roxburghii with the highest antioxidant activity strongly correlated with high amount of kaempferol. ${ }^{23}$ The prominent antiviral results of $P$. roxburghii Wall against NDV confirm their traditional properties in folk medicine where both species are mostly used by the traditional healers to reduce fever, headache and weakness. 3,7-Dimethyl-6-octen-1-ol (41.07\%) and 2-(2-hydroxy-2-propanyl)5 -methylcyclohexanol (14.09\%) were reported as major constituent of total ethanolic extract analyzed by GC/MS. ${ }^{23}$ Cyclohexanol, 5-methyl2-(1-methylethenyl) was previously reported with antimicrobial analgesic, anti-inflammatory, sedative, and antifungal properties. ${ }^{44}$

Acalypha is the fourth largest genus of Euphorbiaceae family. A. wilkesiana leaves has antimicrobial properties. ${ }^{48}$ Due to presence of ellagitannins especially corilagin and geraniin which are reported for their potency as antifungal agents. as it used for treatment of fungal skin infections. Previous studies on A. wilkesiana leaves reported the presence of monoterpenes, sesquiterpenes, triterpenes, saponins, flavonoids, tannins, anthraquinone and glycoside. Previous studies have demonstrated that the dichloromethane fraction obtained from the leaves and bark of $\mathrm{Al}$. moluccana presents antiviral activity against human immunodeficiency virus type- $1 .^{48}$

Aleurites moluccana L. Wild has been reported to endow antimicrobial properties, but little is known about their antiviral activities. Extract from Al. moluccana has showed antibacterial activity against Staphylococcus aureus and Pseudomonas aeruginosa..$^{48}$ To a lesser extent, the anti-viral activity of the aqueous extract of the plant husk part has been reported against herpes simplex virus-1 that significantly exceeded their minimal cellular toxic concentrations. ${ }^{13}$ Phytochemical studies with the plant have revealed the presence of triterpenes, steroids, coumarins and flavonoid glycosides ${ }^{48}$ It is thought that immune enhancement of Al. moluccana is provided by certain flavonoid glycosides moretenone, moretenol, acetilaleuritic acid, moluccanin, and swertisin. The presence of triterpenes, a mixture of $\alpha, \beta$-amyrenone, glutinol, a mixture of $\alpha$, $\beta$-amyrin, friedelenol, stigmasterol, $\beta$-sitosterol, campesterol was reported. These phytochemicals may be attributed to the antiviral activity against HSV types. ${ }^{13}$ The effects of $A$. moluccana' leaves dried hydroalcoholic extract as a natural immune booster could account for its in vitro immunostimulatory effect. ${ }^{13}$ Also, part of the observed effects is due to the presence of the compound 2"-O-rhamnosylswertisin and swertisin. The fact that the extract acted as a disease modifier point this herbal product as a promise and safe tool to treat many chronic diseases. Evaluation of immune boosting properties of different samples was examined in one-day-old SPF chicks. The effects of dietary polyphenols-rich extract supplementation at different levels of $\mathrm{mg} / \mathrm{kg}$ feed on susceptibility of chicken breast meat, thigh meat, liver and heart to iron-induced lipid oxidation were investigated. ${ }^{41}$ At all levels, they exerted antioxidative effects for all tissues. Polyphenolic compounds showed antioxidant efficacy by different strategies like donating hydrogen atoms to free radicals or through binding to transition metal ions resulting in more stable forms. ${ }^{9,41}$ Accordingly, polyphenol showed some physiological activities such as the protection against viral diseases since they have a high antioxidant capacity. The findings of our study show that the hydroalcoholic extract of Breynia distacha J. R. Forst has high content of polyphenolics and flavonoids, the compounds well known with high antioxidant capacity. Furthermore, the antiviral effect probably due to the inhibition of viral replication. ${ }^{41}$

This was in accordance with the increase of published papers about the antiviral and immunomodulatory activities of flavonoids in the last two decades. ${ }^{2,49,50}$ Some of the isolated and identified compounds such as quercetin and kaempferol were previously mentioned in literature that they possess antiviral properties. ${ }^{42}$ Other flavonoids for example; galangin, quercetin, procyanidin and pelargonidin as well as procyanidin $\mathrm{C}-1$ are found to be with virucidal properties.

Previous studies on A. wilkesiana leaves reported the presence of monoterpenes, sesquiterpenes, triterpenes, saponins, flavonoids, tannins, anthraquinone and glycoside. A. wilkesiana leaves has antimicrobial properties. ${ }^{48}$ as it used for treatment of fungal skin infections. In our study, the activity of A. wilkesiana leaves extract may be associated with the presence of geraniin, shikimic acid and quadrangularic acid, the compounds with antimicrobial activity. Corilagin, a compound isolated from A. wilkesiana leaves extract, has exhibited antibacterial and antioxidant activities. ${ }^{48} A$. wilkesiana was reported to enhance the antioxidant capacity of animal and decreased reactive oxygen species mediated oxidation of lipids. ${ }^{12}$ The current study demonstrated the high hemagglutination inhibition HI titer $6.9 \log 2$ in serum of the vaccinated chicks treated with Aleurites moluccana (L.) Willd., Jatropha curcas L., Ricinus communis L., Putranjiva roxburghii 
Wall. with protection percent of $95,95,100$, and $100 \%$, respectively post NDV challenge. 3,30-bis-Demethylpinoresinol, sesquineolignans, neolignans (such as americanol $\mathrm{A}$, isoamericanol $\mathrm{A}$, and isoamericanin A), in major concentrations are the compounds have been associated with antioxidant, cardioprotective, and antitumor activities of Joannesia princeps. ${ }^{22}$ Many chemical groups such as flavonoids, tannins, coumarins, terpenoids, steroids, alkaloids, anthraquinones, acetophenones, xanthones, naphthalenes, and different fatty acids were recorded in the plant. ${ }^{22}$ These herbal plant' phytochemicals influence the immune system by different ways to appreciate the use of them as immunostimulator and veterinary medicinal products. Effect of dietary antioxidant supplementation on the oxidative status of plasma in broilers was reported. ${ }^{2,49}$ When plant extracts rich in polyphenols are added to the meat, their antioxidant properties can be easily observed as there is no problem with their absorption and metabolic changes. These additives are able to improve antioxidant status, immunological indices, and poultry health. Several studies have used complex herbal formulas containing immunostimulant plant on normal and immunodeficient chickens. The administration of the complex drug enhanced humoral immune parameters in both group of chickens., ${ }^{2,49}$

The most common use of Jatropha curcas are for the treatments of antiretroviral, dysentery, fever, inflammatory disorders, and gastric problems..$^{20,21}$ In the current study, the extract of $J$. curcas leaves showed inhibition concentration $50 \%\left(\mathrm{IC}_{50}\right)$ of $\leq 8$ and $\mathrm{CC}_{50}>700$ and therapeutic index $\mathrm{CC}_{50} / \mathrm{IC}_{50}$ of $87.5 \%$. In relation to the constituents contributing to medicinal values, the content of flavonoids and diterpenes, the secondary metabolites with many pharmacological activities such as antiviral and antimicrobial activities, may be considered. ${ }^{2,48,49}$ In previous study, the methanolic extract of J. curcas has showed cycloprotective activity against human immunodeficiency virus type 1 (HIV-1) in cultured human lymphoblastoid CEM-SS cells. ${ }^{21}$ Previous experimental studies conducted by our research group have also demonstrated that the hydroalcoholic extract of Jatropha curcas and its isolates showed imunomodulatory effect on humoral and cellmediated immune response in chicks. Diterpenes isolated from J. curcas fall into six groups including the phorbol esters. From these phorbol esters, the possibility of synthesizing prostratin and 12-deoxyphorbol13-phenylacetate, used for the treatment of HIV was reported. ${ }^{21}$ Also, terpenes and flavonoids have ability to stimulate the cell-mediated immune system, as well as to enhance antibody production. Other compounds such as $\beta$-sitosterol and its glycosides have demonstrated immune modulating activities. ${ }^{50}$ The results of our study showed the presence of sterol molecules such as $\beta$-sitosterol (11.92\%) in the Breynia nivosa (distacha). In this paper, we also evaluate the antiviral activity of Jatropha curcas and R. communis as a part of our ongoing investigation on biological activities from local medicinal plants of Egypt belong to Euphorbiaceae. ${ }^{2,48,49}$

Codiaeum variegatum L. (garden-grown croton species) is an evergreen shrub with often colorful shiny leaves found almost everywhere in Egypt. It is one of today's most decorative and popular ornamental potted plants. Egypt is considered as one of the top three supplying countries of this species (2\%) with China (78\%) and Thailand (14\%). The genus of Codiaeum possesses antimycobacterial and antifungal activities. ${ }^{36}$ It is well reputed for the production of valuable secondary metabolites of cyanoglucosides, alkaloids (glaucine, oxoglaucine and hemiargyrine), anthraquinones, flavanoids, terpenes, steroids, phenols, saponins, tannins, phlobatannin and cardenolide. ${ }^{51}$ The antiviral activity of a cyanoglucoside; 2-(3,4,5)-trihydroxy-6hydroxymethyltetrahydropyran-2-yloxymethyl) acrylonitrile isolated from C. variegatum was reported. ${ }^{38}$ The compound displayed virucidal activity without impairment of hemagglutination properties of the used influenza A virus strain. C. variegatum extracts showed effective DPPH free radical scavenging, hydrogen peroxide radical scavenging and nitric oxide scavenging activity. Ellagic acid was abundantly present phenolic compound in the extract and pentadecadien-1-ol and hexadecanoic acid were abundant volatiles in garden croton leaves extract analyzed using GC/MS. ${ }^{51}$

Ricinus communis, known as wonder tree, is an important traditional medicine plant in Egypt. It is a perennial scrub probably originates from Africa and was used in ancient Egypt and by the Romans and Greeks. ${ }^{4}$ The mechanism of dimeric cytotoxins of this plant as active antiviral was reported to the interaction with ribosome function in the infected cell and inhibit viral protein synthesis. Previous experimental studies conducted by our research group have also demonstrated that the hydroalcoholic extract of $R$. communis $\mathrm{L}$. leaves exhibit free radical scavenging activity. ${ }^{4}$ The activity might be attributed to the presence of various phytochemicals of minerals, protein, lipids, carbohydrates. Other compounds were also quantitatively estimated (polyphenolics, flavonoids, anthocyanins, tannin). The antiviral properties of this plant support their traditional uses in cold and fever which are in most cases viral symptoms.

The majority of the extracts were active against the two viruses, but there was considerable variation among them. Low HI titer (6.4 $\log 2)$ was recorded in serum of the vaccinated chicks treated with Synadenium grantii Hook F. with protection percent of $80 \%$ post NDV challenge. Synadenium grantii Hook F. is commonly called African Milk Bush. It is a succulent shrub or small tree. In nature, the plants will reach up to 12 feet in height with an equal spread. The pale green obolanceolate, slightly toothed leaves reach 6 inches. Furthermore, the immuno-regulatory properties from the Synadenium genus have been reported in association with its chemical constituents; diterpenoids, triterpenoids and anthocyanins. However, from the genus Synadenium; S. grantii Hook F. leaves and stems contained glycosides, flavonoids and terpenoids, alkaloids, tannins, tigliane, senadenol, phorbol type diterpenoids.

There is a strong correlation for some plants, e.g, Aleurites moluccana (L.) Willd., Breynia distacha J. R. Forst., Jatropha curcas L., Ricinus communis L., and Putranjiva roxburghii Wall. For other plants, the correlation seems less obvious. This might suggest a discrepancy at the diagnostic level or at the prescription level, meaning that the plant may have other uses than infectious diseases. It may also mean difficulty for a healer to diagnose infectious diseases.

\section{CONCLUSION}

The results showed the potential of B. distacha J. R. Forst., Aleurites moluccana (L.) Willd., Acalypha wilkesiana Müll. Arg., E. mauritanica, J. curcas L., R. communis L., P. roxburghii Wall. and J. princeps Vell. B to be new candidates of plant based prototypes that exhibit antiviral and immunogenic features against the most important respiratory tract infection pathogens; AIV H5N1 and NDV, significantly threatening the poultry sector. The crude hydroalcoholic extract of $B$. distach $a$ uniquely showed $\mathrm{CC}_{50}$ values of $>200$ and $>300$ and $\mathrm{IC}_{50}$ values of $\leq 2$ and $\leq 3$ against NDV and AIV H5N1, respectively, with antiviral therapeutic index $\left(\mathrm{CC}_{50} / \mathrm{IC}_{50}\right)$ of $100 \%$. The serum of the vaccinated chicks treated with $B$. distacha has, as well, recorded the highest HI titers $(7.1 \log 2$ and $8.3 \log 2$ ) with high protection percents (100 and 90\%) post NDV and AIV H5N1 challenge, respectively. This significant outcomes will be aimed at protecting Egyptian poultry flock from multiple respiratory viral infections that has huge socio-economic impact by the potential development of locally-available natural resources and directing future studies against other viruses. Isolation and identification of the antiviral compounds of the most active extract is being investigated currently.

\section{FUNDING}

The authors wish to thank the financial support of National Research Centre, Egypt. This work was a part from Contract No. AR 11215. 


\section{REFERENCES}

1. Cos P, Vlietinck AJ, Berghe DV, Maes L. Anti-infective potential of natural products: how to develop a stronger in vitro 'proof-of-concept'. Journal of Ethnopharmacology. 2006;106(3):290-302

2. Abd-Alla HI, Heba-tollah MS, Mohamed TA, Gabr MM, El-Safty MM, Hegazy ME. Efficacy of extracts and iridoid glucosides from Pentas lanceolata on humoral and cell-mediated immune response of viral vaccine. Medicinal Chemistry Research. 2017;26(9):2196-204.

3. Laamiri N, Fällgren P, Zohari S, Ali JB, Ghram A, Leijon M, et al. Accurate detection of avian respiratory viruses by use of multiplex PCR-based luminex suspension microarray assay. Journal of Clinical Microbiology. 2016;54(11):271625.

4. Henderson J, Morkot R, Peltenburg EJ, Quirke S, Serpico M, Tait J, et al. Ancient Egyptian materials and technology. Cambridge University Press; 2000; 390-428

5. Kim SH, Samal SK. Innovation in Newcastle Disease Virus Vectored Avian Influenza Vaccines. Viruses. 2019;11(3):300.

6. Sharif A, Ahmad T, Umer M, Rehman A, Hussain Z. Prevention and control of Newcastle disease. International Journal of Agriculture Innovations and Research. 2014;3(2):454-60

7. Suarez DL. Evolution of avian influenza viruses. Veterinary microbiology. 2000;74(1-2):15-27.

8. Kusumoto IT, Nakabayashi T, Kida H, Miyashiro $H$, Hattori M, Namba T, Shimotohno K. Screening of various plant extracts used in ayurvedic medicine for inhibitory effects on human immunodeficiency virus type 1 (HIV-1) protease. Phytotherapy Research. 1995;9(3):180-4

9. Mwine JT, Van Damme P. Why do Euphorbiaceae tick as medicinal plants? A review of Euphorbiaceae family and its medicinal features. Journal of Medicinal Plants Research. 2011;5(5):652-62.

10. Boulos L. Flora and vegetation of the deserts of Egypt. Flora Mediterranean. 2008; 18:341-59.

11. Banjo AD, Lawal OA, Aina SA. The entomofauna of two medicinal, Euphorbiaceae in Southwestern Nigeria. Journal Applied Science Research. 2006;2(11):858-63.

12. Forcados GE, Chinyere CN, Shu ML. Acalypha wilkesiana: therapeutic and toxic potential. Journal of Medical and Surgical Pathology.2016;1(3):122-3.

13. Quintão NL, Pastor MV, Antonialli CD, da Silva GF, Rocha LW, Berté TE, et al. Aleurites moluccanus and its main active constituent, the flavonoid 2 "-O-rhamnosylswertisin, in experimental model of rheumatoid arthritis. Journal of Ethnopharmacology. 2019;235:248-54.

14. Olowokudejo JD, Kadiri AB, Travih VA. An ethnobotanical survey of herbal markets and medicinal plants in Lagos State of Nigeria. Ethnobotanical Leaflets. 2008;12(1):851-65.

15. Salatino A, Salatino ML, Negri G. Traditional uses, chemistry and pharmacology of Croton species (Euphorbiaceae). Journal of the Brazilian Chemical Society. 2007;18(1):11-33

16. Nashikkar N, Begde D, Bundale S, Pise M, Rudra J, Upadhyay A. Inhibition of swarming motility, biofilm formation and virulence factor expression of urinary pathogens by Euphorbia trigona latex extracts. International Journal of Pharmaceutical Sciences and Research. 2011;2(3):558.

17. Guenther F, Maus D, Hedtrich S, Melzig MF. Serine protease Mauritanicain from Euphorbia mauritanica and phorbol-12-myristate-13-acetate modulate the IL-8 release in fibroblasts and HaCaT keratinocytes. Planta Medica. 2019;85(7):57882.

18. Lee MT, Lin WC, Lee TT. Potential crosstalk of oxidative stress and immune response in poultry through phytochemicals-A review. Asian-Australasian Journal of Animal Sciences. 2019;32(3):309.

19. Kamurthy H, Dontha S. Phytochemical screening on Euphorbia milii red flowers-Isolation of terpenoids, flavone and phenols. American Journal of Ethnomedicine. 2015;2(6):322-32.

20. Abdelgadir HA, Van Staden J. Ethnobotany, ethnopharmacology and toxicity of Jatropha curcas L. (Euphorbiaceae): A review. South African Journal of Botany. 2013; 88:204-18.

21. Mazumdar $P$, Singh $P$, Babu S, Siva R, Harikrishna JA. An update on biological advancement of Jatropha curcas L.: New insight and challenges. Renewable and Sustainable Energy Reviews. 2018;91:903-17.

22. Araújo AC, Guiguer EL, Barbalho SM, Bueno PC, Lopes JA, da Silva BF, et al. Phytochemical characteristics of seeds and its effects on the intestinal motility and toxicity of Joannesia princeps. Journal of Medicinal Food. 2016;19(1):68-72.

23. Supriya B, Vijayakumar K, Subramanian N, Kumar D. Medicinal values of Putranjiva roxburghii-a review. International Journal of Current Pharmaceutical Research. 2017;9(5):5-8.

24. Gomes EH, Soares FE, Souza DC, Lima LT, Sufiate BL, Ferreira TF, Queiroz $\mathrm{JH}$. Role of Synadenium grantii latex proteases in nematicidal activity on Meloidogyne incognita and Panagrellus redivivus. Brazilian Journal of Biology. 2019;79(4):665-8.
25. Office International Des Epizooties, (OIE). Manual of Standards for Diagnostic Tests and Vaccines. 4th ed. Paris, France: OIE; 2002.

26. Hobson D, Curry RL, Beare AS, Ward-Gardner A. The role of serum haemagglutination-inhibiting antibody in protection against challenge infection with influenza A2 and B viruses. Epidemiology and Infection. 1972;70(4):767-77.

27. Abd-Alla HI, Abu-Gabal NS, Hassan AZ, El-Safty MM, Shalaby NM. Antiviral activity of Aloe hijazensis against some haemagglutinating virus's infection and its phytoconstituents. Archives of Pharmacal Research. 2012;35(8):1347-54.

28. El-Safty MM, Mahmoud H, Zaki EA, Abd-Alla HI. Preparation and evaluation of chemically inactivated Salmonella enteritidis vaccine in chickens. Asian Journal of Pharmaceutical and Clinical Research. 2017;10 (11):341-6.

29. Fathy M, El-Safty MM, El-Jakee J, Abd-Alla HI, Mahmoud H. Study the effect of Mycoplasma contamination of eggs used in virus titration and efficacy of some live attenuated poultry viral vaccines. Asian Journal of Pharmaceutical and Clinical Research. 2017;10(1):216-22.

30. Palache AM, Beyer WE, Rimmelzwaan GF, Boon AC, Osterhaus $A D$. Haemagglutination-inhibiting antibody to influenza virus. Developments in Biologicals. 2003;115:63-73.

31. Code of American Federal Regulations national archives and records administration (2012). Biological products: General, title 21, volume 7 part 600.

32. Kaur P, Mehta RG, Singh B, Arora S. Development of aqueous-based multiherbal combination using principal component analysis and its functional significance in HepG2 cells. BMC Complementary and Alternative Medicine. 2019;19(1):18-35.

33. Iverson JL, Shepperd AJ. Programmed temperature gas chromatographic analysis of esters of fatty acids. Journal of Chromatographic Science. 1975;13(10):505-8.

34. Adams RP. Identification of essential oils by ion trap mass spectroscopy. Academic press; 2012 Dec 2.

35. Zhao Y, Geng CA, Ma YB, Huang XY, Chen H, Cao TW, et al. UFLC/MS-IT-TOF guided isolation of anti-HBV active chlorogenic acid analogues from Artemisia capillaris as a traditional Chinese herb for the treatment of hepatitis. Journal of Ethnopharmacology. 2014; 156:147-54.

36. Gautam R, Saklani A, Jachak SM. Indian medicinal plants as a source of antimycobacterial agents. Journal of Ethnopharmacology. 2007;110(2):200-34.

37. Kpodékon TM, Ogni CA, Dassou H, Dougnon TJ, Boko C, Koutinhouin GB, et al. Dominant viral pathologies in the extensive and semi-intensive animal breeding and their treatment mode in ethno veterinary medicine in Benin. Veterinary World. 2015;8(12):1424-34.

38. Njoroge GN, Bussmann RW. Herbal usage and informant consensus in ethnoveterinary management of cattle diseases among the Kikuyus (Central Kenya). Journal of Ethnopharmacology. 2006;108(3):332-9.

39. Forero JE, Avila L, Taborda N, Tabares P, López A, Torres F, et al. In vitro anti-influenza screening of several Euphorbiaceae species: Structure of a bioactive Cyanoglucoside from Codiaeum variegatum. Phytochemistry. 2008;69(16):2815-9.

40. Ghoke SS, Sood R, Kumar N, Pateriya AK, Bhatia S, Mishra A, et al. Evaluation of antiviral activity of Ocimum sanctum and Acacia arabica leaves extracts against H9N2 virus using embryonated chicken egg model. BMC Complementary and Alternative Medicine. 2018;18(1):174.

41. Abid S, Touqeer S. Antimicrobial and antioxidant activity of Breynia disticha and Vernonia elaeagnifolia. Journal of Applied Pharmacy. 2015;7:178-82.

42. Rojas Á, Del Campo JA, Clement S, Lemasson M, García-Valdecasas M, GilGómez $A$, et al. Effect of quercetin on hepatitis $C$ virus life cycle: from viral to host targets. Scientific Reports. 2016;6:31777.

43. Furuta A, Tsubuki M, Endoh M, Miyamoto T, Tanaka J, Salam K, et al. Identification of hydroxyanthraquinones as novel inhibitors of hepatitis $\mathrm{C}$ virus NS3 helicase. International Journal of Molecular Sciences. 2015;16(8):1843953.

44. Wang H, Xu R, Shi Y, Si L, Jiao P, Fan Z, et al. Design, synthesis and biological evaluation of novel L-ascorbic acid-conjugated pentacyclic triterpene derivatives as potential influenza virus entry inhibitors. European Journal of Medicinal Chemistry. 2016;110:376-88.

45. Zhou QM, Zhu $H$, Feng $R$, Peng $C$, Yang $H$, Liu F, et al. New triterpenoids from Leonurus japonicus (Lamiaceae). Biochemical Systematics and Ecology. 2019;82:27-30.

46. Krawitz C, Mraheil MA, Stein M, Imirzalioglu C, Domann E, Pleschka S, et al. Inhibitory activity of a standardized elderberry liquid extract against clinicallyrelevant human respiratory bacterial pathogens and influenza $A$ and $B$ viruses. BMC Complementary and Alternative Medicine. 2011;11(1):16. https://doi. org/10.1155/2018/2048530

47. Perera SD, Jayawardena UA, Jayasinghe CD. Potential Use of Euphorbia hirta for Dengue: A Systematic Review of Scientific Evidence. Journal of Tropical Medicine. 2018;2018. 
48. Anokwuru CP, Sinisi A, Samie A, Taglialatela-Scafati O. Antibacterial and antioxidant constituents of Acalypha wilkesiana. Natural Product Research. 2015;29(12):1180-3

49. Maghraby AS, Shalaby N, Abd-Alla HI, Ahmed SA, Khaled HM, Bahgat MM. Immunostimulatory effects of extract of Pulicaria crispa before and after Schistosoma mansoni infection. Acta Polonia Pharmaceutica. 2010;67(1):75-9
50. Abd-Alla HI, Moharram FA, Gaara AH, El-Safty MM. Phytoconstituents of Jatropha curcas L. leaves and their immunomodulatory activity on humoral and cell-mediated immune response in chicks. Zeitschrift für Naturforschung C. 2009;64(7-8):495-501.

51. Bouic PJ. Sterols and sterolins: new drugs for the immune system? Drug Discovery Today. 2002;7(14):775-8.

\section{GRAPHICAL ABSTRACT}

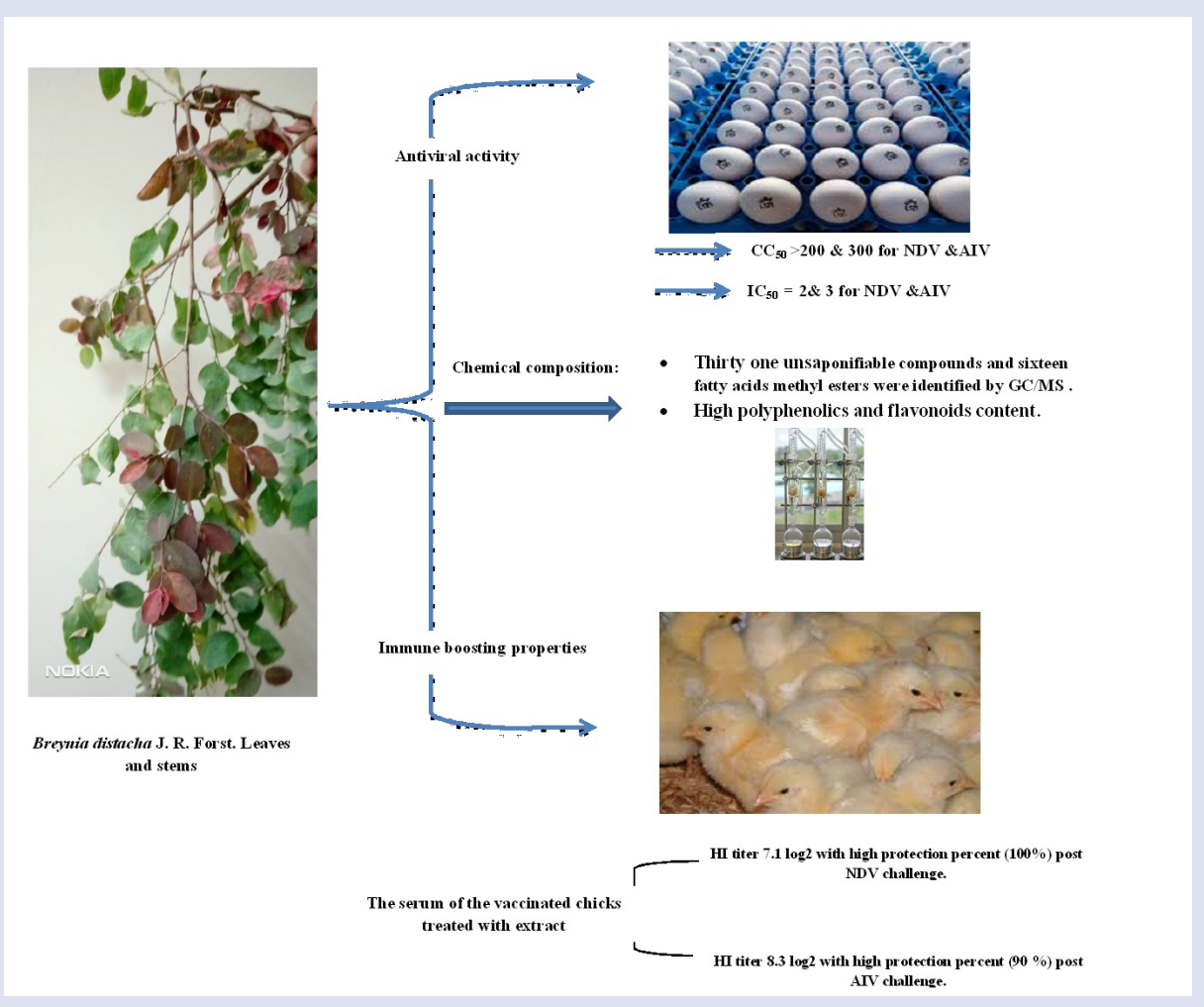

\section{ABOUT AUTHORS}
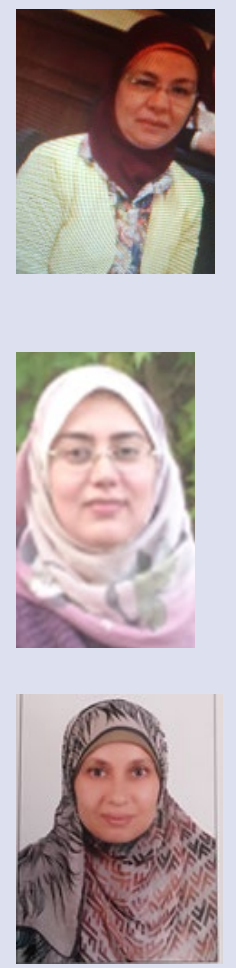

Abd-Alla has got her PhD in Pharmaceutical Sciences, Cairo Univ., Fac. Pharmacy (2004). She has over 65 publications in peer reviewed journals and attended different international conferences in drug delivery and technology field. She has got a postdoctoral research grant funded from the Institut francais d'Egypte in Univ. de Toulouse, France. She upgraded to professor since August, 2014 to date. Currently, she works as a head of Chemistry of Natural Compounds Department. She obtained many local prizes and the Scientific Excellence Prize of King Abdul-Aziz University, KSA. The research interest of her focuses primarily on isolation and identification of natural compounds from medicinal plants, bacteria and marine organisms using high technique, synthesis of derivatives of natural products, and bioactive assay against different diseases.

Heba-Tollah M. I. Sweelam PhD from Botany and Microbiology Department, Cairo University (2019). She is currently working as an assistant researcher in the National Research Centre (NRC), Pharmaceutical, and Drug Industries Division, Chemistry of Natural Compounds Department.

She has experience in the quantification and analysis of different plant constituents such as carbohydrates, proteins, lipids, volatile oil, and macro- and microelements. She has expertise in the phytochemical screening, extraction and isolation of some bioactive compounds by several chromatographic techniques. She is also practicing different tissue culture techniques as well as different screening methods to determine antimicrobial activity of natural products.

Walaa A. El-kashak is an associate professor in the National Research Centre (NRC), Pharmaceutical, and Drug Industries Division, Chemistry of Natural Compounds Department.

She has experience in; isolation, identification of phenolic compounds (flavonoids, phenolic acids and coumarins) from medicinal plants by different methods (PC, paper electrophoresis, TLC, CC, HPLC and MPLC), separation techniques using various adsorbent in different chromatographic methods, and identification of compunds by different spectroscopic techniques including NMR; one and two dimension analysis techniques and by mass spectrometric techniques (EI, ESI and HR/MS). 


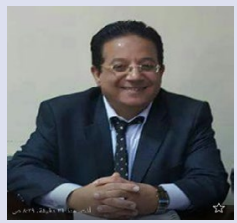

El-Safty has got his PhD in Veterinary Medicine Science, Faculty of Veterinary Medicine, Cairo University in May 1997. He works at the Central Laboratory for Evaluation of Veterinary Biologics (CLEVB) as the head of the Evaluation of Poultry Virus Vaccines Department and Quality Control for Specific Pathogen Free (SPF) eggs unit. He was successful with his team to obtain a certificate of the Accreditation ISO 17025 (extraneous virus 4 methods and quality control SPF eggs unit 6 methods) and also, the same accreditation in sterility bacterial unit 4 methods. He is a member of the ministerial committee as well and participating in committee's evaluation of local and imported viral poultry vaccines. Currently, he is the chairman for the National Project for the Production of SPF Eggs (April 2010 till now).

Cite this article: Abd-Alla HI, Sweelam HM, El-KashakWA, El-Safty MM. Evaluation of Immune Boosting Properties and Combating of Multiple Respiratory Viral Infections by fifteen Euphorbiaceae Plant Extracts. Pharmacog J. 2019;11(6)Suppl:1490-1503. 